Prepared in cooperation with the U.S. Army Corps of Engineers, Louisville District

\title{
Potential Interaction of Groundwater and Surface Water Including Autonomous Underwater Vehicle Reconnaissance at Nolin River Lake, Kentucky, 2016
}

Seientific investigations Report 201955075 
Cover. Photograph from the perspective of an autonomous underwater vehicle completing a mission in the Dog Creek Arm of the reservoir, August 2016. Photograph by Justin Boldt, U.S. Geological Survey. 


\section{Potential Interaction of Groundwater and Surface Water Including Autonomous Underwater Vehicle Reconnaissance at Nolin River Lake, Kentucky, 2016}

By Angela S. Crain, Justin A. Boldt, E. Randall Bayless, Aubrey R. Bunch, Jade L. Young, Jennifer C. Thomason, and Zachary L. Wolf

Prepared in cooperation with the U.S. Army Corps of Engineers, Louisville District

Scientific Investigations Report 2019-5075 


\title{
U.S. Department of the Interior DAVID BERNHARDT, Secretary
}

\author{
U.S. Geological Survey \\ James F. Reilly II, Director
}

U.S. Geological Survey, Reston, Virginia: 2019

For more information on the USGS - the Federal source for science about the Earth, its natural and living resources, natural hazards, and the environment-visit https://www.usgs.gov or call 1-888-ASK-USGS.

For an overview of USGS information products, including maps, imagery, and publications, visit https://store.usgs.gov.

Any use of trade, firm, or product names is for descriptive purposes only and does not imply endorsement by the U.S. Government.

Although this information product, for the most part, is in the public domain, it also may contain copyrighted materials as noted in the text. Permission to reproduce copyrighted items must be secured from the copyright owner.

Suggested citation:

Crain, A.S., Boldt, J.A., Bayless, E.R., Bunch, A.R., Young, J.L., Thomason, J.C., and Wolf, Z.L., 2019, Potential interaction of groundwater and surface water including autonomous underwater vehicle reconnaissance at Nolin River Lake, Kentucky, 2016: U.S. Geological Survey Scientific Investigations Report 2019-5075, 36 p., https://doi.org/10.3133/sir20195075.

ISSN 2328-0328 (online) 


\section{Acknowledgments}

The authors and the U.S. Geological Survey gratefully recognize the contributions of

the Nolin River Lake Park Manager, Deryck Rodgers, and the U.S. Army Corps of Engineers staff at Nolin River Lake.

Sincere thanks to Molly K. Lott (U.S. Geological Survey), Faye E. Peters (U.S. Geological Survey) and Mac A. Cherry (formerly U.S. Geological Survey and now U.S. Forest Service) for assisting with field work. We are grateful to Angela K. Brennan and Celeste A. Journey, U.S. Geological Survey, for providing thorough technical reviews. 


\section{Contents}

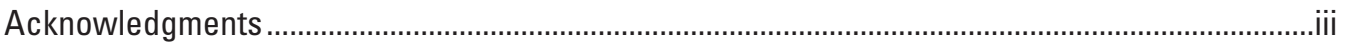

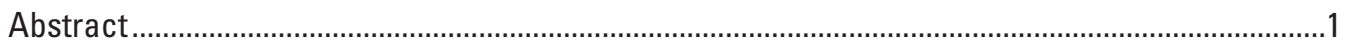

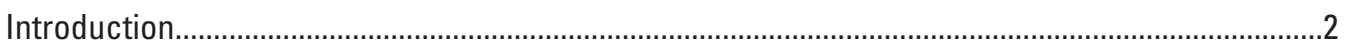

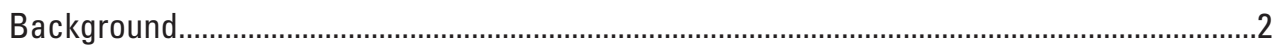

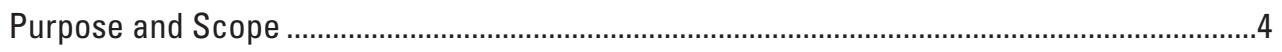

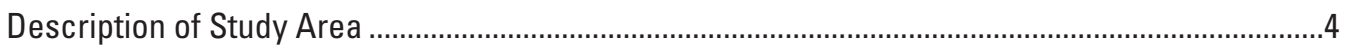

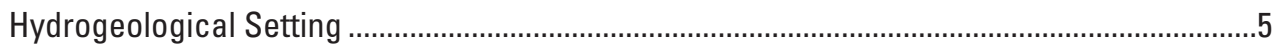

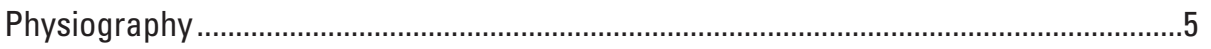

Geology

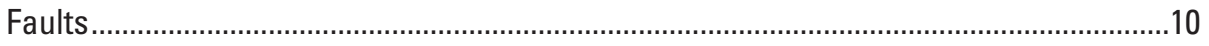

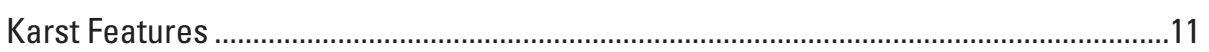

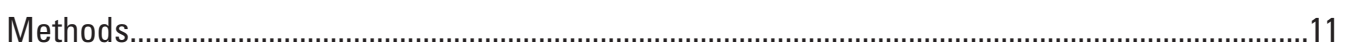

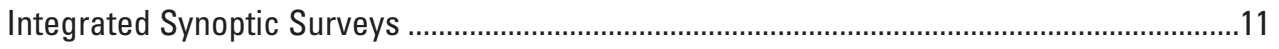

Discrete Data Collection and Analysis Methods..............................................................12

Autonomous Underwater Vehicle Data Processing ..................................................................... 14

Potential Interaction of Groundwater and Surface Water at Nolin River Lake..............................21

Reservoir Water-Quality Data during August 15-19, 2016 ........................................................21

Water-Quality Data Measured with the Autonomous Underwater Vehicle ...........................21

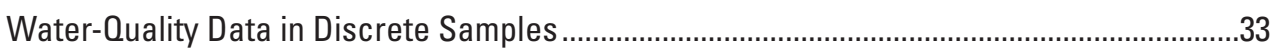

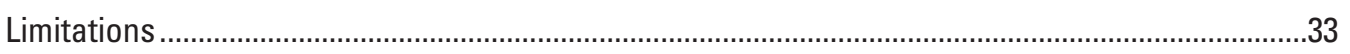

Summary

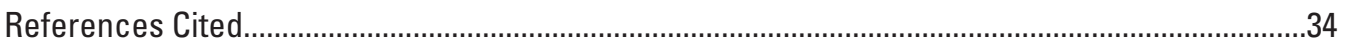

\section{Figures}

1. Map showing location of the study area and data collection sites

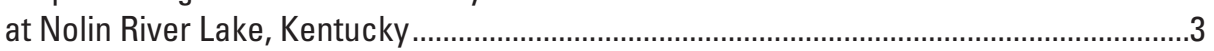

2. Map showing potential for karst development in the Nolin River Lake watershed ......................................................................................6

3. Map showing generalized near-surface bedrock in the Nolin River Lake watershed ...................................................................................

4. Map showing near-surface bedrock at Nolin River Lake ................................................

5. Map showing faults and karst features at Nolin River Lake ..........................................10

6. Maps showing synoptic survey field with designated survey lines for sites on Nolin River Lake, August 15-19, 2016 ..................................................................13

7. Map showing water temperature at 5 feet below the surface

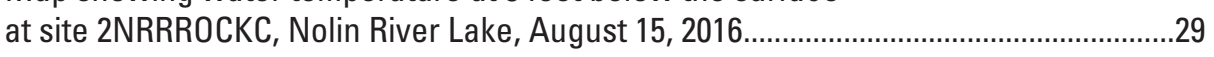

8. Map showing chlorophyll values at 15 feet below the surface at site 2NRR20003, Nolin River Lake, August 17, 2016

9. Map showing chlorophyll values in the surface layer at site 2NRR20034, Nolin River, August 19, 2016 


\section{Tables}

1. Descriptions of geologic units in the vicinity of Nolin River Lake (summarized from Gildersleeve, 1971)...

2. Manufacturer's specifications for the water-quality sensors aboard

the autonomous underwater vehicle

3. Sampling locations and depths at Nolin River Lake, Kentucky, August 15-19, 2016

4. Summary statistics of water-quality parameters at Nolin River Lake, Kentucky, August 15-19, 2016.

5. Summary of nutrient, chlorophyll $a$, and pheophytin a concentrations in discrete-depth samples from Nolin River Lake, August 15-19, 2016

6. Cyanobacterial abundance in discrete water-quality samples collected at Nolin River Lake, August 15-19, 2016.

\section{Conversion Factors}

U.S. customary units to International System of Units

\begin{tabular}{lcl}
\hline & Multiply & By obtain \\
\hline inch (in.) & Length & \\
foot (ft) & 2.54 & centimeter $(\mathrm{cm})$ \\
mile (mi) & 0.3048 & meter $(\mathrm{m})$ \\
\hline & 1.609 & kilometer $(\mathrm{km})$ \\
\hline acre & Area & \\
square mile $\left(\mathrm{mi}^{2}\right)$ & 4,047 & square meter $\left(\mathrm{m}^{2}\right)$ \\
\hline & 2.590 & square kilometer $\left(\mathrm{km}^{2}\right)$ \\
\hline gallon (gal) & Volume & liter $(\mathrm{L})$ \\
gallon (gal) & 3.785 & cubic meter $\left(\mathrm{m}^{3}\right)$ \\
cubic foot $\left(\mathrm{ft}^{3}\right)$ & 0.003785 & cubic meter $\left(\mathrm{m}^{3}\right)$ \\
\hline
\end{tabular}

Temperature in degrees Celsius $\left({ }^{\circ} \mathrm{C}\right)$ may be converted to degrees Fahrenheit $\left({ }^{\circ} \mathrm{F}\right)$ as follows:

$$
{ }^{\circ} \mathrm{F}=\left(1.8 \times{ }^{\circ} \mathrm{C}\right)+32 \text {. }
$$

\section{Datum}

Vertical coordinate information is referenced to the North American Vertical Datum of 1988 (NAVD 88). Horizontal coordinate information is referenced to the North American Datum of 1983 (NAD 83). Elevation, as used in this report, refers to distance above the vertical datum. 


\section{Supplemental Information}

Specific conductance is given in millisiemens per centimeter at 25 degrees Celsius ( $\mathrm{mS} / \mathrm{cm}$ at $\left.25^{\circ} \mathrm{C}\right)$.

Concentrations of chemical constituents in water are given in either milligrams per liter (mg/L) or micrograms per liter ( $\mu \mathrm{g} / \mathrm{L})$. Chemical concentrations and water temperature are given in metric units.

A milligram per liter is a unit expressing the concentration of chemical constituents in solution as mass (milligrams) of solute per unit volume (liter) of water. For water with dissolved-solids concentrations less than $7,000 \mathrm{mg} / \mathrm{L}$, the numerical value for milligrams per liter is the same as for concentrations in parts per million.

A concentration of $1,000 \mu \mathrm{g} / \mathrm{L}$ is equivalent to $1 \mathrm{mg} / \mathrm{L}$. For water with dissolved-solids concentrations less than $7,000 \mathrm{mg} / \mathrm{L}$, the numerical value for micrograms per liter is the same as for concentrations in parts per billion.

\section{Abbreviations}

$\begin{array}{ll}\text { ArcGIS } & \text { Aeronautical Reconnaissance Coverage Geographic Information System } \\ \text { ASCII } & \text { American Standard Code for Information Interchange } \\ \text { AUV } & \text { autonomous underwater vehicle } \\ \text {.CSV } & \text { comma-separated value } \\ { }^{\circ} \text { C } & \text { degrees Celsius } \\ \text { DO } & \text { dissolved oxygen } \\ \text { EPA } & \text { U.S. Environmental Protection Agency } \\ \text { FNU } & \text { formazin nephelometric units } \\ \text { GPS } & \text { global positioning system } \\ \text { HABs } & \text { harmful algal blooms } \\ \text { MATLAB } & \text { matrix laboratory } \\ \mu \text { /L } & \text { micrograms per liter } \\ \text { mg/L } & \text { milligrams per liter } \\ \text { mS/cm } & \text { millisiemens per centimeter at 25 degrees Celsius } \\ \text { SC } & \text { specific conductance } \\ \text { USACE } & \text { U.S. Army Corps of Engineers } \\ \text { USGS } & \text { U.S. Geological Survey }\end{array}$




\title{
Potential Interaction of Groundwater and Surface Water Including Autonomous Underwater Vehicle Reconnaissance at Nolin River Lake, Kentucky, 2016
}

\author{
By Angela S. Crain, ${ }^{1}$ Justin A. Boldt, ${ }^{1}$ E. Randall Bayless, ${ }^{1}$ Aubrey R. Bunch, ${ }^{1}$ Jade L. Young, ${ }^{2}$ \\ Jennifer C. Thomason, ${ }^{2}$ and Zachary L. Wolf ${ }^{2}$
}

\section{Abstract}

The U.S. Geological Survey collaborated with the U.S. Army Corps of Engineers, Louisville District, on a synoptic study of water quality at Nolin River Lake during August 2016. The purpose of the study was to develop a better understanding of the potential for interaction between groundwater and surface water at Nolin River Lake, Kentucky. Groundwater can have properties that are measurably different from those in adjacent surface water, and inflows and outflows can be an important component of water quality and quantity. An improved understanding of potential interaction of groundwater and surface water at Nolin River Lake may be used to refine lake-management strategies. This study (1) compiled and interpreted existing information to characterize the hydrogeological setting and implications for potential interaction of groundwater and surface water in the Nolin River Lake watershed; (2) collected transects of onsite water-quality parameters using an autonomous underwater vehicle (AUV) in areas with potential for interaction of groundwater and surface water, including five sites on Nolin River Lake and one site on the Nolin River; and (3) collected discrete water-quality and phytoplankton community data at the same six sites.

A review of existing hydrogeologic information did not indicate the presence of karst features adjacent to or beneath Nolin River Lake that would facilitate groundwater interaction with the reservoir. Observations leading to this conclusion include (1) limestone that is adjacent to the shoreline and perhaps beneath the lake, is overlain with siliciclastic rocks and fine-grained sediment that inhibits infiltration and development of karst features that encourage rapid groundwater flow; (2) the geologic deposits surrounding the reservoir are described as having limited or no potential for development of karst features, some exceptions may exist in tributary valleys; (3) very few karst features were mapped within 1 mile of the reservoir or in the area currently occupied by

\footnotetext{
${ }^{1}$ U.S. Geological Survey.
}

${ }^{2}$ U.S. Army Corps of Engineers. the reservoir; and (4) faults that intersect the reservoir but may not possess hydraulic properties that cause the faults to be conduits for groundwater flow. Groundwater interaction with reservoir tributaries is likely more common in areas of the watershed upstream from Nolin River Lake where karst hydrogeology is prevalent.

Results of water-quality surveys using an AUV from August 15 to 19, 2016, did not identify areas of anomalous values that might indicate groundwater inflows through preferential flow zones. Spatial distributions of water-quality parameters were generally uniform within each constant-depth layer. The constant-depth layers were selected to be above, within, and below the thermocline and ranged from the water surface to 25 feet. Surveys near the bottom of the reservoir that might have been more sensitive to groundwater inflows were not done because presurvey data were not available to indicate locations of obstacles that could ensnare the AUV. Water-quality data collected with the AUV did identify waterquality anomalies where stream tributaries were discharging to the reservoir.

The discrete water-quality samples indicated uniformity among the five reservoir sites. The riverine site that is immediately upstream from Nolin River Lake, however, had some unique water-quality characteristics relative to sites on the reservoir. The highest concentrations of nitrate plus nitrite as nitrogen $(0.145$ milligrams per liter $[\mathrm{mg} / \mathrm{L}])$, total phosphorous $(0.07 \mathrm{mg} / \mathrm{L})$, chlorophyll $a$ (36.1 micrograms per liter), and pheophytin $a$ (10.2 micrograms per liter) were measured at the Nolin River Lake riverine site (site 2NRR20034). The concentrations of nutrients and chlorophyll $a$ at the riverine site did exceed the 25th percentile of median concentrations measured by the U.S. Environmental Protection Agency (EPA) at other lakes and reservoirs in EPA level IV ecoregion 71a. Concentrations of most nutrients and chlorophyll $a$ at the five reservoir sites also exceeded the 25th percentile of median concentrations in EPA level IV ecoregion 72h. The exception was the concentrations of total phosphorus as phosphorus at the reservoir sites that were at or below the 25th percentile of median concentrations measured by EPA $(0.03 \mathrm{mg} / \mathrm{L})$. Concentrations of orthophosphate as phosphorus were less 
than the method detection limit of $0.004 \mathrm{mg} / \mathrm{L}$ at all sites. The phytoplankton community in Nolin River Lake was almost exclusively (greater than 90 percent of total phytoplankton abundance) cyanobacteria, also known as bluegreen algae. A species of Cylindrospermopsis dominated the cyanobacterial community at the five reservoir sites, while Chroococcus microscopicus was most abundant at the riverine site. Cyanobacterial cell densities ranged from 10,000 to $198,067,460$ cells per liter in five areas in the reservoir and from 4,800 to $73,751,253$ cells per liter at the riverine site.

Multiple potential sources of water to Nolin River Lake include direct precipitation, overland flow, interflow, groundwater, and surface water. Understanding the exact contribution of each of these components to the water budget at Nolin River Lake may help the U.S. Army Corps of Engineers manage the water quality, water quantity, and biological communities in the reservoir. Additional hydrogeologic and waterquality data that builds on the results of this study may refine the inferences of this study; for example, deeper AUV surveys that target the largest fault zones might further the understanding of the potential for groundwater flow through those features. A complete understanding of the reservoir hydrology, however, may require the use of scientific methods intended for water bodies as large as Nolin River Lake, such as aerial infrared photography and imagery; water mass, chemical, and isotopic balance studies; geophysical measurements; and numerical simulations.

\section{Introduction}

The U.S. Geological Survey (USGS), in cooperation with the U.S. Army Corps of Engineers (USACE), completed a study during August 2016 that evaluated the potential interaction of groundwater and surface water at Nolin River Lake (hereafter referred to as the reservoir), Kentucky (fig. 1). The use of the reservoir has been occasionally restricted by harmful algal blooms (HABs) (Kentucky Department for Environmental Protection, 2014) and one study indicated that groundwater discharges of nutrients to the reservoir could fuel the blooms. An understanding of the potential interaction of groundwater and surface water at Nolin River Lake is needed to manage the water and biological quality in the reservoir.

As part of this study, the USGS and USACE (1) compiled and interpreted existing information to characterize the hydrogeological setting and implications for potential interaction of groundwater and surface water in the Nolin River Lake watershed; (2) collected transects of onsite water-quality parameters using an autonomous underwater vehicle (AUV) in areas where groundwater discharges to the reservoir were suspected, including five sites on Nolin River Lake and one site on the Nolin River; and (3) collected discrete water-quality and phytoplankton community data at the same six sites. This report describes the existing hydrogeology in the Nolin River watershed with a focus on the area immediately surrounding
Nolin River Lake; documents the methods used to collect, analyze, and interpret the water-quality and phytoplankton data; and examines the information for indications of the exchange of water between the reservoir and adjacent geologic deposits. The raw data can be accessed through the project data release at https://doi.org/10.5066/F798857D (Crain and others, 2019).

\section{Background}

Groundwater and surface water are intimately connected, and effective resource management requires understanding that connection (Rosenberry and LaBaugh, 2008). The location, quality, and rate of groundwater discharge to (or from) surface water may vary seasonally and with changing hydrologic conditions, and the effects on ecosystems are not static. Techniques for measuring the exchange of water and chemical constituents between groundwater and surface water depend on the purpose of the investigation, the desired accuracy, the scale of the study area, and the hydrologic conditions (Rosenberry and LaBaugh, 2008).

The technique selected to measure potential interaction of groundwater with surface water should be appropriate for the purpose, accuracy, scale, and hydrologic condition. Many of the methods for measuring the exchange between groundwater and surface water are intended for smaller study scales than the entirety of Nolin River Lake (Rosenberry and LaBaugh, 2008). Methods more appropriate to the scale of Nolin River Lake include aerial infrared photography and imagery, geophysical surveys, measured water chemistry or isotope balance, and numerical simulation models (Rosenberry and LaBaugh, 2008). Locations of rapid discharge from groundwater to surface water, as might be expected if preferential-flow zones created by karst features or rock fractures intersected the shoreline and reservoir bottom, have been identified in some studies by using boat-tethered temperature and specific-conductance probes (Rosenberry and LaBaugh, 2008). This process follows that the use of an AUV equipped with probes to acquire onsite measurements of water temperature, dissolved oxygen (DO) concentration, $\mathrm{pH}$, specific conductance (SC), turbidity, total chlorophyll as fluorescence (estimate of algal biomass), and phycocyanin as fluorescence (estimate of cyanobacteria biomass) could reveal the location of zones of enhanced groundwater inflow that intercept the shoreline and bottom of Nolin River Lake.

Many factors may affect the rate and location of groundwater discharge to adjacent surface water. Depending on the distribution of hydraulic heads through time, water may also seep from the reservoir into underlying geologic deposits. Factors that may affect groundwater discharge at Nolin River Lake include the hydrogeologic properties and thickness of unconsolidated sediments that form the bottom of the reservoir, the distribution of hydraulic-heads in the reservoir and the geologic deposits beneath and surrounding the reservoir, the three-dimensional architecture and orientation of hydraulic properties of geologic deposits and rock units 

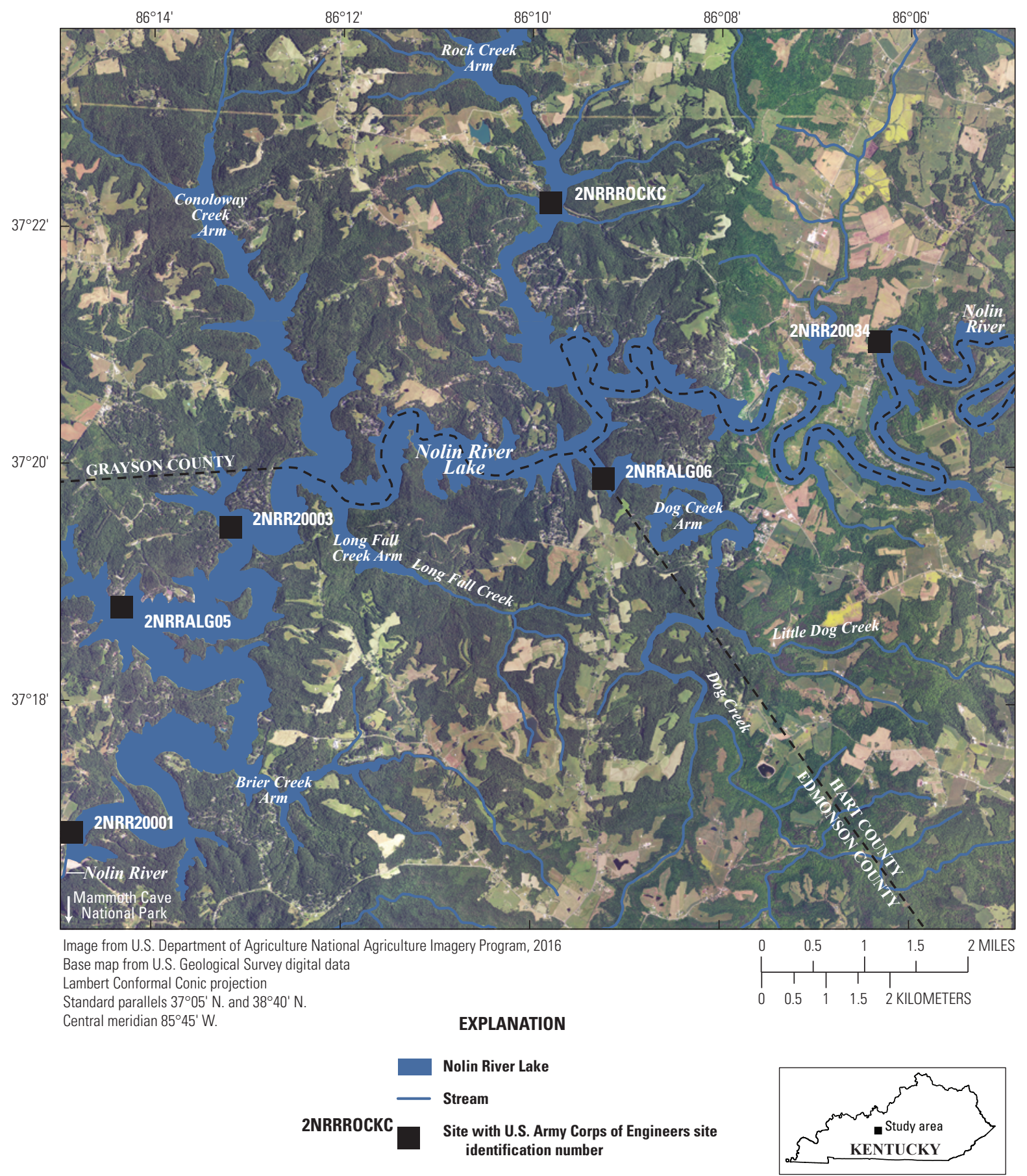

Figure 1. Location of the study area and data collection sites at Nolin River Lake, Kentucky.

intersecting the reservoir, and the presence of faults and karst features that may act as zones of preferential flow between groundwater systems and the reservoir (Rosenberry and LaBaugh, 2008).

Nolin River Lake is a water-supply source for citizens in the region and a popular recreational site. The use of the reservoir has been occasionally restricted by the occurrence of HABs. During 2013 and 2014, Nolin River Lake was one of five reservoirs in Kentucky where the USACE issued recreational advisories for concentrations of cyanobacteria exceeding 100,000 cells per milliliter (Kentucky Department for Environmental Protection, 2014). The USACE, under its jurisdictions, monitors cyanobacteria populations in reservoirs, and the Kentucky Division of Water monitors cyanobacteria populations at 18 additional non-USACE reservoirs. 
HABs have been determined to adversely affect the health of humans and animals by skin contact or ingestion (Kentucky Department for Environmental Protection, 2014; U.S. Environmental Protection Agency, 2018). Water-quality standards have been proposed for recreational contact and consumption of water containing microcystin, a hepatotoxin produced by Microcystis and some other cyanobacteria (Kentucky Department for Environmental Protection, 2014). The World Health Organization guideline is a microcystin limit of 1.0 part per billion for consumption and 4.0 parts per billion (low risk) to 20 parts per billion (moderate risk) for recreational contact (Kentucky Department for Environmental Protection, 2014). The U.S. Environmental Protection Agency (EPA) does not have a maximum contaminant level for algal toxins.

HABs in freshwater systems are caused by factors that include light availability, water temperature, altered water flow, vertical mixing, $\mathrm{pH}$ changes, nutrient (nitrogen and phosphorous) loading, and trace metals (U.S. Environmental Protection Agency, 2017). HABs are not always, however, correlated with human-related pollution (Chorus and Bartram, 1999). Cyanobacteria may have a higher affinity and storage capability for nitrogen and phosphorous compounds and out compete other photosynthetic organisms for supplies, thereby explaining the occurrence of some blooms when nutrient concentrations are lowest (Chorus and Bartram, 1999). Cyanobacteria blooms favor lower nitrogen to phosphorous ratios than exist during other periods. Periods of higher turbidity and the resulting lower light penetration is a favored condition of cyanobacteria. Maximum cyanobacteria production occurs at temperatures exceeding 25 degrees Celsius $\left({ }^{\circ} \mathrm{C}\right)$.

A study by Schaefer (2016) indicated that "karst" groundwater influenced the chemistry and biology of Nolin River Lake. Schaefer (2016) used weather records, measured populations of Escherichia.coli (E. coli), isotopes, and general chemistry $(\mathrm{pH}$, temperature, $\mathrm{SC}$, salinity, and DO) in surface water from August 2015 to March 2016 to identify the sources of nutrients to Nolin River Lake. Groundwater was deduced to be the source of water-quality constituents capable of fueling HABs because the concentrations of those constituents were not identified in streams that were monitored and discharged to the reservoir between August and March 2016.

Recognizing the results of Schaefer (2016), the USACE selected six sites from its regularly monitored network to evaluate for potential interaction of groundwater and surface water. During August 2016, the USGS and USACE collected, analyzed, and interpreted water-quality and phytoplankton data in areas of Nolin River Lake where conditions might favor the potential interaction of groundwater and surface water. Following the collection of water-quality data, existing geological information was compiled and summarized to characterize the hydrogeology at Nolin River Lake. Data collection included multidepth transects of onsite waterquality parameters using an AUV and discrete sampling for chemical constituents and phytoplankton. Water-quality data or phytoplankton characteristics that were anomalous relative to the larger collection of data might indicate groundwater discharge from a karst feature.

\section{Purpose and Scope}

The purpose of this report is to (1) characterize the hydrogeology near the reservoir and identify characteristics that favor the potential interaction of groundwater and surface water and (2) describe the methods used to collect, analyze and interpret water-quality and phytoplankton data at Nolin River Lake during August 2016 and identify spatial anomalies that could represent groundwater inflows through karst features. During the study, data were collected and analyzed from five areas of Nolin River Lake and from one site on the Nolin River where conditions might favor interaction of groundwater and surface water. The hydrogeological evaluation focused on the area immediately surrounding and beneath the reservoir but considered the entire Nolin River Lake watershed.

\section{Description of Study Area}

Nolin River Lake is a manmade reservoir in Edmonson, Grayson, and Hart Counties in south-central Kentucky near Mammoth Cave National Park (fig. 1). The reservoir was created by damming the Nolin River (fig. 1) and provides flood control, drinking-water supplies, recreational benefits, and fish and wildlife habitat (U.S. Army Corps of Engineers, 2018). Dam construction was completed with the water level reaching minimum pool elevation in 1963. The USACE, Louisville District, in cooperation with the Commonwealth of Kentucky, manages Nolin River Lake State Park land and water (U.S. Army Corps of Engineers, 2018).

The study area includes the 703 square miles that defines the Nolin River Lake surface-water watershed (U.S. Army Corps of Engineers, 2011); however, the area of the groundwater watershed may be different as a result of karstic conditions that exist beneath the Western Pennyroyal Karst Plateau. The study area includes parts of Edmonson, Grayson, and Hart Counties in west-central Kentucky (fig. 1).

The water-surface elevation in Nolin River Lake is controlled by the USACE. During 2016, the water-surface elevation ranged from about 492 to 522 feet (ft; above the North American Vertical Datum of 1988 [NAVD 88]). The elevation of the normal winter pool is $490 \mathrm{ft}$ and the summer pool is $515 \mathrm{ft}$ (U.S. Army Corps of Engineers, 2011). The USACE report does not specify the vertical datum, but upon further investigation, it was determined that these pool levels are referenced to the National Geodetic Vertical Datum of 1929 (NGVD 29). These pool levels were converted to NAVD 88 using a datum shift value of $-0.39 \mathrm{ft}$ obtained 
from VERTCON (National Geodetic Survey, 2019). Therefore, $490 \mathrm{ft}$ (NGVD 29) is $489.61 \mathrm{ft}$ (NAVD 88), and $515 \mathrm{ft}$ (NGVD 29) is $514.61 \mathrm{ft}$ (NAVD 88). During summer pool (when this study was completed) the surface area of the reservoir is approximately 5,795 acres and the reservoir is about 30 miles (mi) long (Kleber, 1992).

The climate of the Nolin River Lake watershed is humid subtropical (Climate-Data.org, 2018). The average annual temperature in Leitchfield, Kentucky, the county seat of Grayson County and approximately $16 \mathrm{mi}$ north of the reservoir, is $12{ }^{\circ} \mathrm{C}$. Temperatures are generally warmest from May through September. Average annual precipitation is 48.55 inches. The driest months generally occur from August through September (U.S. Climate Data, 2017).

Two EPA level IV ecological regions encompass Nolin River Lake. The upper part of the reservoir, near site 2NRR20034 (fig. 1), is associated with the Crawford-Mammoth Cave Uplands ecoregion (level IV ecoregion 71a). The CrawfordMammoth Cave Uplands ecoregion is composed of hilly uplands containing cliffs and wide karst valleys (Woods and others, 2002). Sinkholes, caverns, springs, and subterranean drainage are common; however, surface drainage can be substantial. Below site 2NRR20034, the reservoir is associated with the Caseyville Hills ecoregion (level IV ecoregion 72h). This ecoregion is dominated by forests and pasturelands, and is underlain by sandstones, siltstones, shales, and coal. Limestone is much less common than in the Crawford-Mammoth Cave Uplands ecoregion (Woods and others, 2002). An ecoregion is defined as a region that has similar biological, chemical, and geographic characteristics within the terrestrial and aquatic compartments of its ecological system (Omernik, 1987).

\section{Hydrogeological Setting}

Information to describe the hydrogeological setting was collected from a variety of sources including maps, journals, reports, theses, books, and websites. The information was used to determine the existence of permeable bedrock adjacent to or underlying the reservoir and zones of preferential groundwater flow related to karst features or structural faulting. The existence of these characteristics would indicate an unquantified potential for groundwater to discharge to or from Nolin River Lake.

\section{Physiography}

A physiographic region or province is a region with characteristic geomorphology that is often related to the underlying geology and geologic history of the area. The study area is within the Western Kentucky Coal Field and Pennyroyal physiographic regions of Kentucky. Most of Nolin River Lake is within the eastern part of the Western Kentucky Coal Field Region. Western Kentucky Coal Field terrain is characterized by rugged hills with steep-sided valleys (Carey and Hounshell, 2008). The part of the study area within the Western Kentucky Coal Field Region is formed on bedrock units comprised of sandstone, siltstone, shale, and some coal (Carey and Hounshell, 2008).

The eastern part of the Nolin River Lake watershed, containing the headwaters and most of the contributing area for the reservoir, is within the Pennyroyal Region of the Commonwealth. The part of the study area within the Pennyroyal Region is formed on mixed bedrock types that include limestone, sandstone, shale, siltstone, and clay. Limestone units are responsible for the karst topography and hydrogeology that are visually apparent at land surface in the Pennyroyal Region and can strongly impact the flow and quality of water. Near Nolin River Lake, the Pennyroyal and Western Kentucky Coal Field Regions are separated by an escarpment that marks the boundary between the more erosion resistant sandstones of the Western Kentucky Coal Field Region and the more soluble and erodible limestones of the Pennyroyal Region (George, 1989).

The Kentucky Geological Survey has classified most of the Nolin River watershed as having high potential or moderate potential for karst development (fig. 2). Land near the reservoir is classified as having limited or no potential for karst development; however, the land that forms some of the shoreline immediately adjacent to the reservoir is classified as having moderate potential for karst development.

\section{Geology}

The geology of Nolin River Lake and the greater watershed is complex. Multiple lithology types are present with varying geochemical and hydraulic properties. Karst development, faulting, and local and regional bedrock dips complicate the geologic architecture. The upper reaches of the Nolin River watershed are dominated by limestone, but siliciclastic shales and siltstones are more prominent near land surface in the area immediately surrounding Nolin River Lake (fig. 3).

A geological map of the area immediately surrounding Nolin River Lake shows the presence of the following formations or members of Mississippian age: the Girkin Formation; the Big Clifty Sandstone and the Haney Limestone Members, both of the Golconda Formation; the Hardinsburg Sandstone; the Glen Dean Limestone; the Vienna Limestone Member; and the Leitchfield Formation (fig. 4, table 1). Also shown on the geological map are the Caseyville Formation and Tradewater and Caseyville Formations of Pennsylvanian age; the Quaternary period deposits of alluvium; and the Holocene epoch artificial fill material (fig. 4, table 1).

The hydraulic properties of the rock types at Nolin River Lake vary greatly. Water may flow through the primary permeability or secondary permeability of the rock. Primary permeability describes the rate that water flows through the interconnected pores that separate individual mineral grains. Secondary permeability describes the rate that water flows through rock features that have been created by rock dissolution or fracturing. In general, shale and siltstone have lower primary permeability than sandstone. The primary 


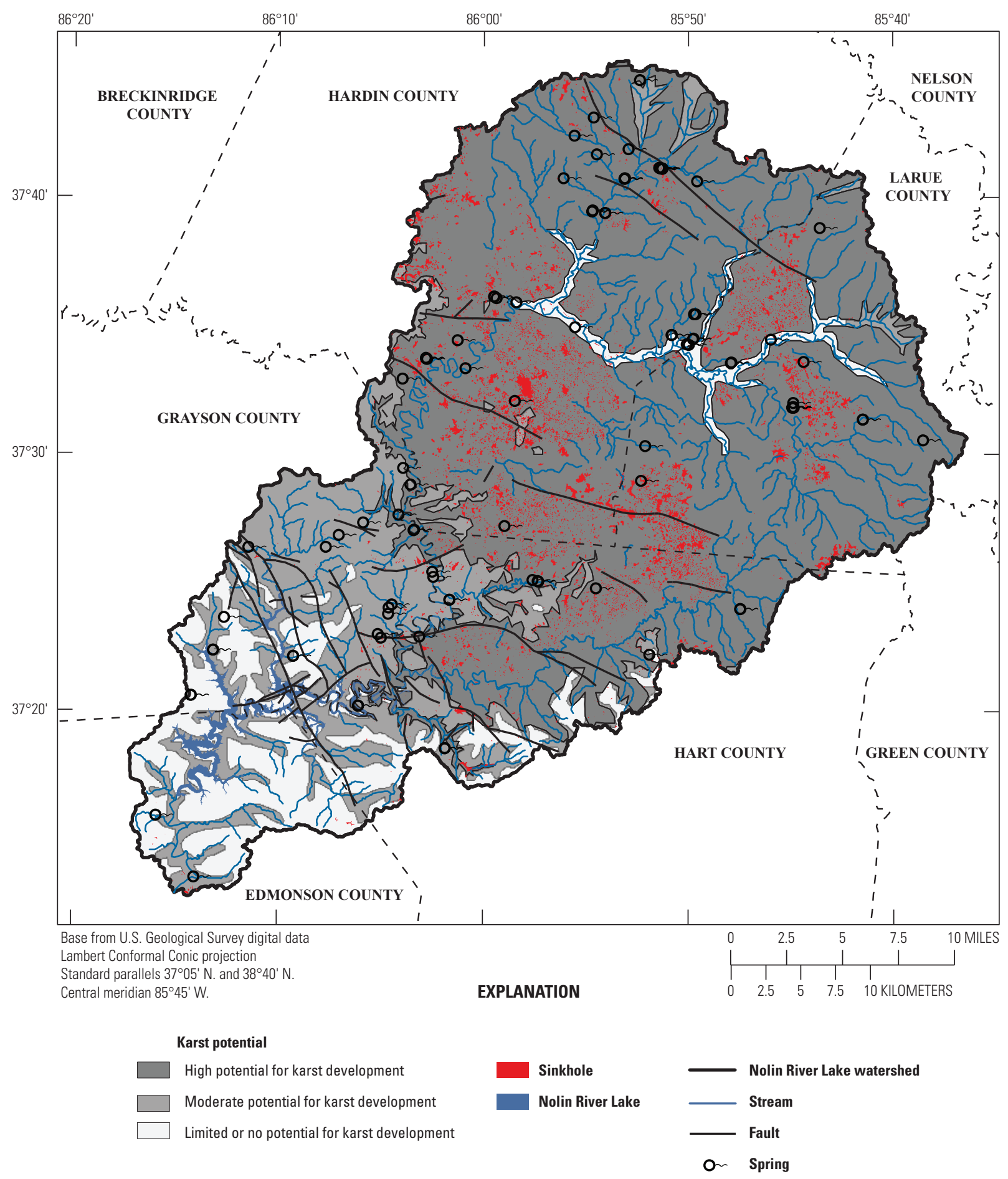

Figure 2. Potential for karst development in the Nolin River Lake watershed.

permeability of limestone is lower in dense fine-grained rock and higher in coarse-grained units. Limestone can be dissolved by rock interaction with naturally occurring organic acids and develop significant secondary porosity along bedding planes, joints, and fractures. Karst features are the result of limestone dissolution. All rock types can have enhanced secondary permeability created by structural faulting.

The direct hydrologic interaction of groundwater with the reservoir requires that water-transmitting geologic units be in contact with the shoreline or reservoir bottom. Based on 


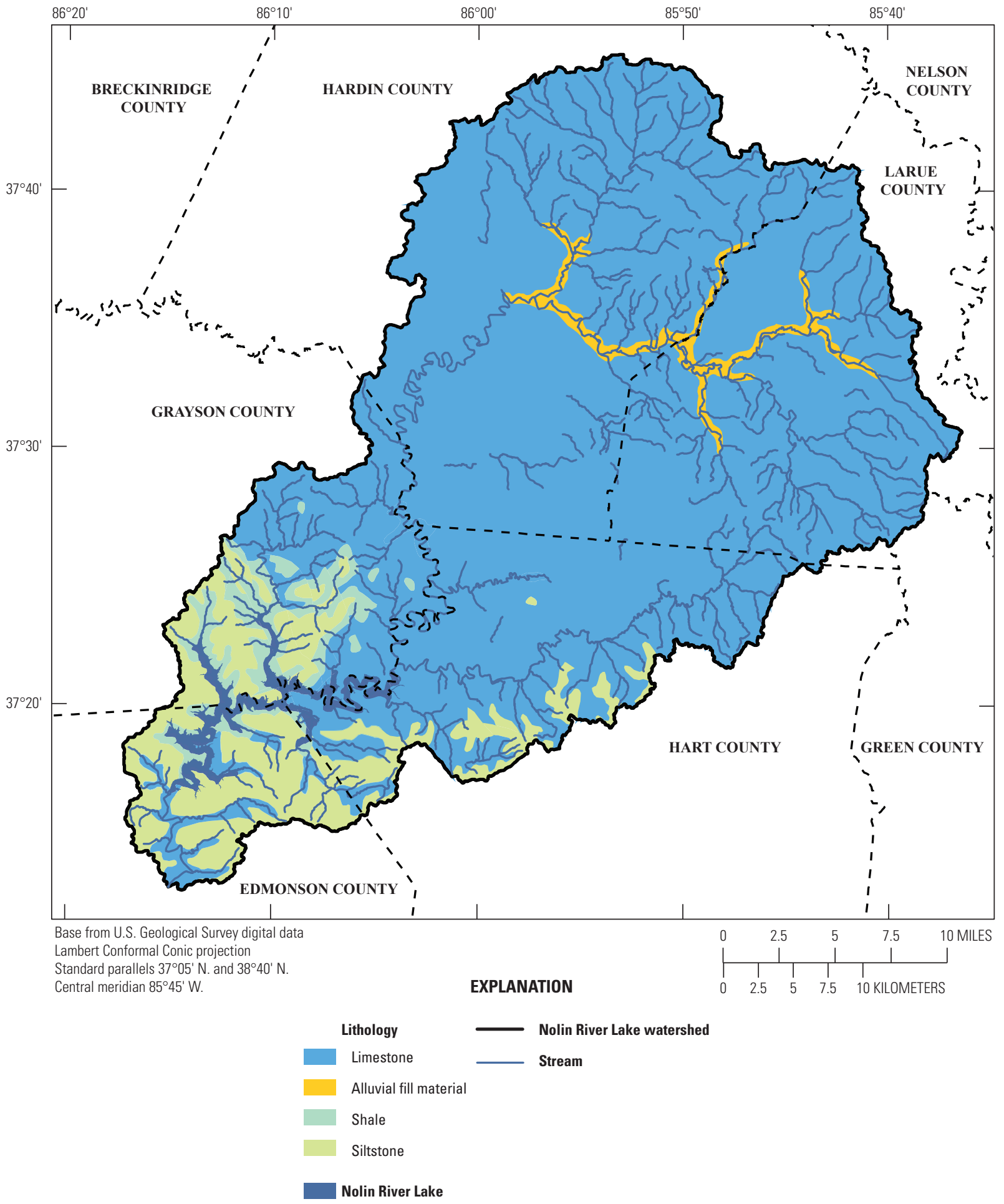

Figure 3. Generalized near-surface bedrock in the Nolin River Lake watershed.

mapping by Gildersleeve (1971), the geologic units in contact with the reservoir shoreline include the Big Clifty Sandstone Member, Haney Limestone Member, Hardinsburg Sandstone, and Glen Dean Limestone (fig. 4). The Haney Limestone Member appearance at the reservoir shoreline is limited and appears mostly in the Brier Creek Arm area in the southeastern part of the study area with smaller exposures in the Dog Creek and Little Dog Creek tributary valleys (fig. 1, fig. 4). The Hardinsburg Sandstone occurs along the reservoir in the Brier Creek Arm, in a limited area of Long Fall Creek Arm, 


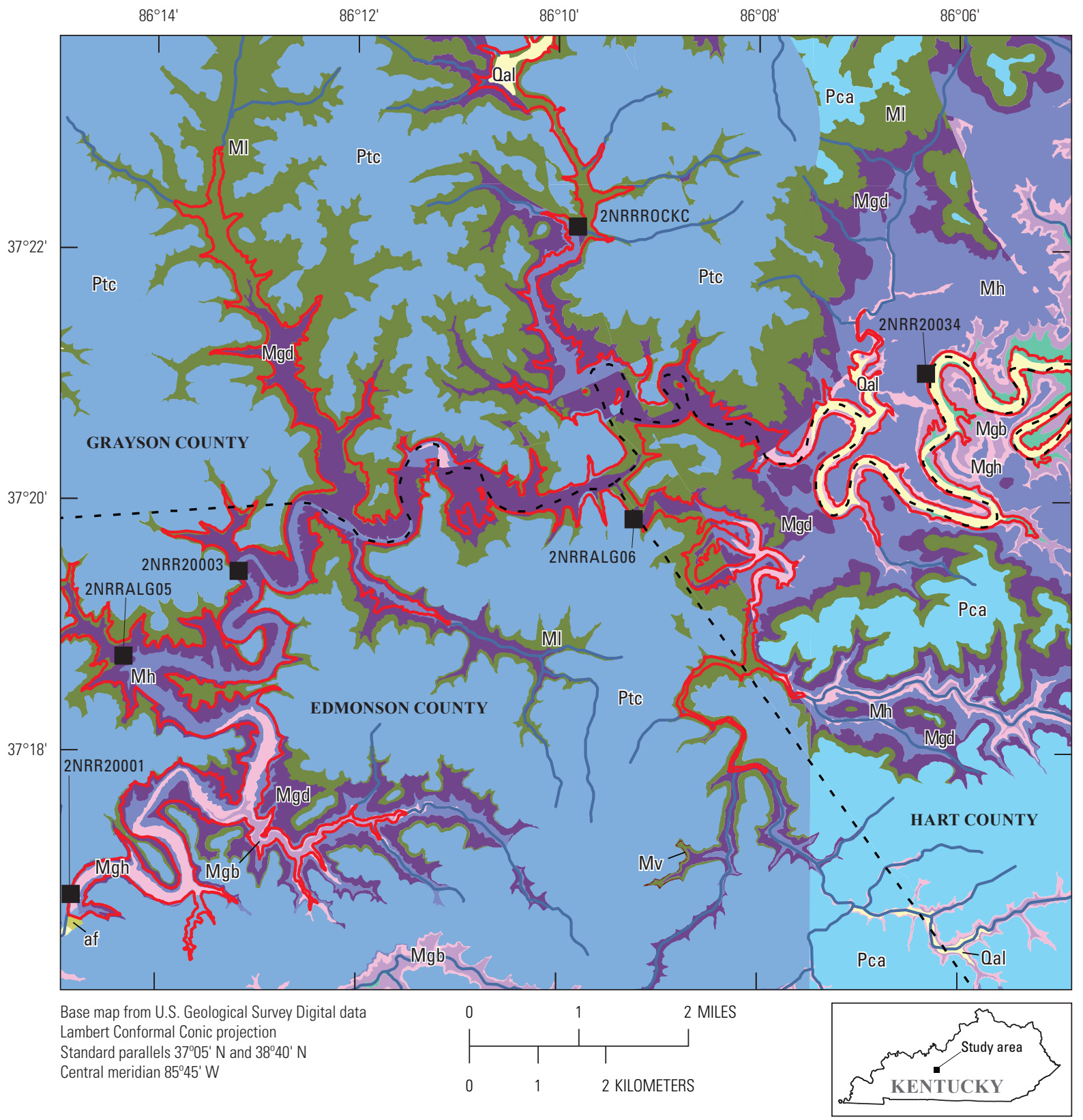

EXPLANATION

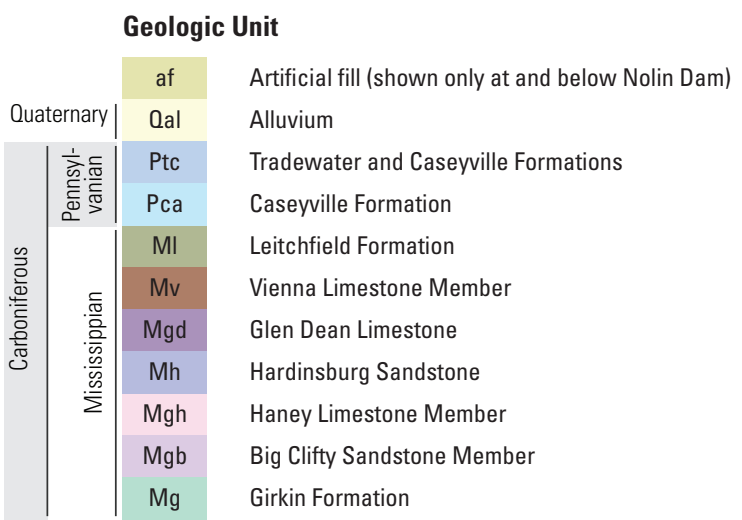

Outline of Nolin River Lake

Streams

- - - County lines

Site with U.S. Army Corps of Engineers site number

Figure 4. Near-surface bedrock at Nolin River Lake. 
Table 1. Descriptions of geologic units in the vicinity of Nolin River Lake (summarized from Gildersleeve, 1971).

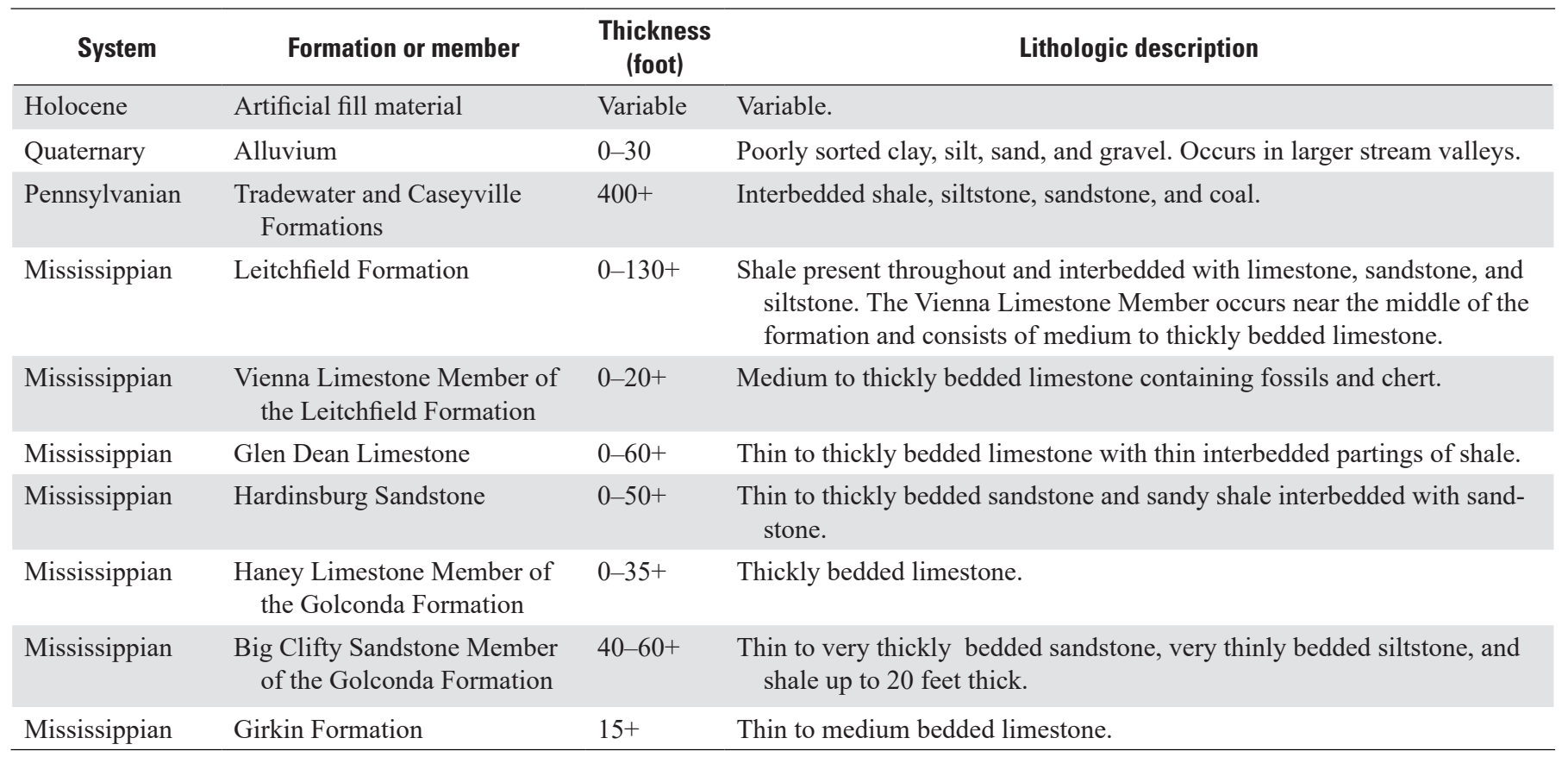

Dog Creek and Little Dog Creek Arms, and upper reaches of the reservoir where Nolin River enters the reservoir (fig. 1, fig. 4). The Glen Dean Limestone is present at the reservoir shoreline in the Long Fall Creek Arm and the Rock Creek Arm (fig. 1) and may form the lakebed beneath unconsolidated deposits throughout most of the reservoir. The Leitchfield Formation occurs at the reservoir along most of the northern shoreline and the Dog Creek Arm (fig. 1, fig. 4). Most of the uplands away from the reservoir are capped with siliciclastic (noncarbonate) Tradewater and Caseyville Formations (Gildersleeve, 1971). The bedrock units that form the bottom of the reservoir are unclear; however, Gildersleeve (1971) indicates that, although covered with unconsolidated deposits, the bedrock forming the bottom of the reservoir is likely Big Clifty Sandstone Member, Haney Limestone Member, Hardinsburg Sandstone, Glen Dean Limestone, and Leitchfield Formation depending on position in the reservoir.

Two sites where water-quality data were collected as part of this study were near shorelines made of limestone. Site 2NRRROCKC has one shoreline made of Haney Limestone Member, but the other is of the weather-resistant Leitchfield Formation (fig. 4). One shoreline near site 2NRR20034 may be partly made of Haney Limestone Member. Four of the sites on the reservoir sampled for water quality (2NNR20001, 2NRRALG05, 2NRR20003, and 2NRRALG06) and mapped with the AUV are near shorelines made of the less karst-prone Leitchfield Formation and Tradewater and Caseyville Formations bedrock (fig. 4).
The bedrock units at Nolin River Lake are part of the Illinois structural basin. In the study area, bedrock strata generally dip to the west (U.S. Army Corps of Engineers, 2011). Structural contours drawn on bedrock units near the reservoir; however, indicate that bedrock dip is locally complex (Gildersleeve, 1971). South of the reservoir, bedrock dips radially away from Mammoth Cave National Park to the northeast, north, and northwest. North of the reservoir, bedrock dips toward the Conoloway Creek Arm. Regional groundwater flow paths in the bedrock flow in the direction of the bedrock dip (Gildersleeve, 1971).

Unconsolidated deposits mantle the bedrock surface in most of the study area. The thickness of the unconsolidated deposits in the uplands surrounding the reservoir are reported on well-drillers' records that range from 3 to $13 \mathrm{ft}$ (University of Kentucky and Kentucky Geological Survey, 2018). Unconsolidated deposits are primarily made of thin soils developed on clay and silt-rich materials. The hydraulic properties of the unconsolidated deposits likely promote slow infiltration of precipitation to the bedrock units and may generate large quantities of overland flow during intense rainfall events.

The thickness and hydraulic properties of unconsolidated deposits that blanket the bottom of the reservoir are unknown. Generally, bottom sediments in reservoirs are made of organic detritus and fine-grained material like silt and clay that is transported into the reservoir by streams and overland flow and settles to the reservoir bottom during quiescent periods. Those sediments generally have low permeability that inhibits the interaction of groundwater with the reservoir bottom. 


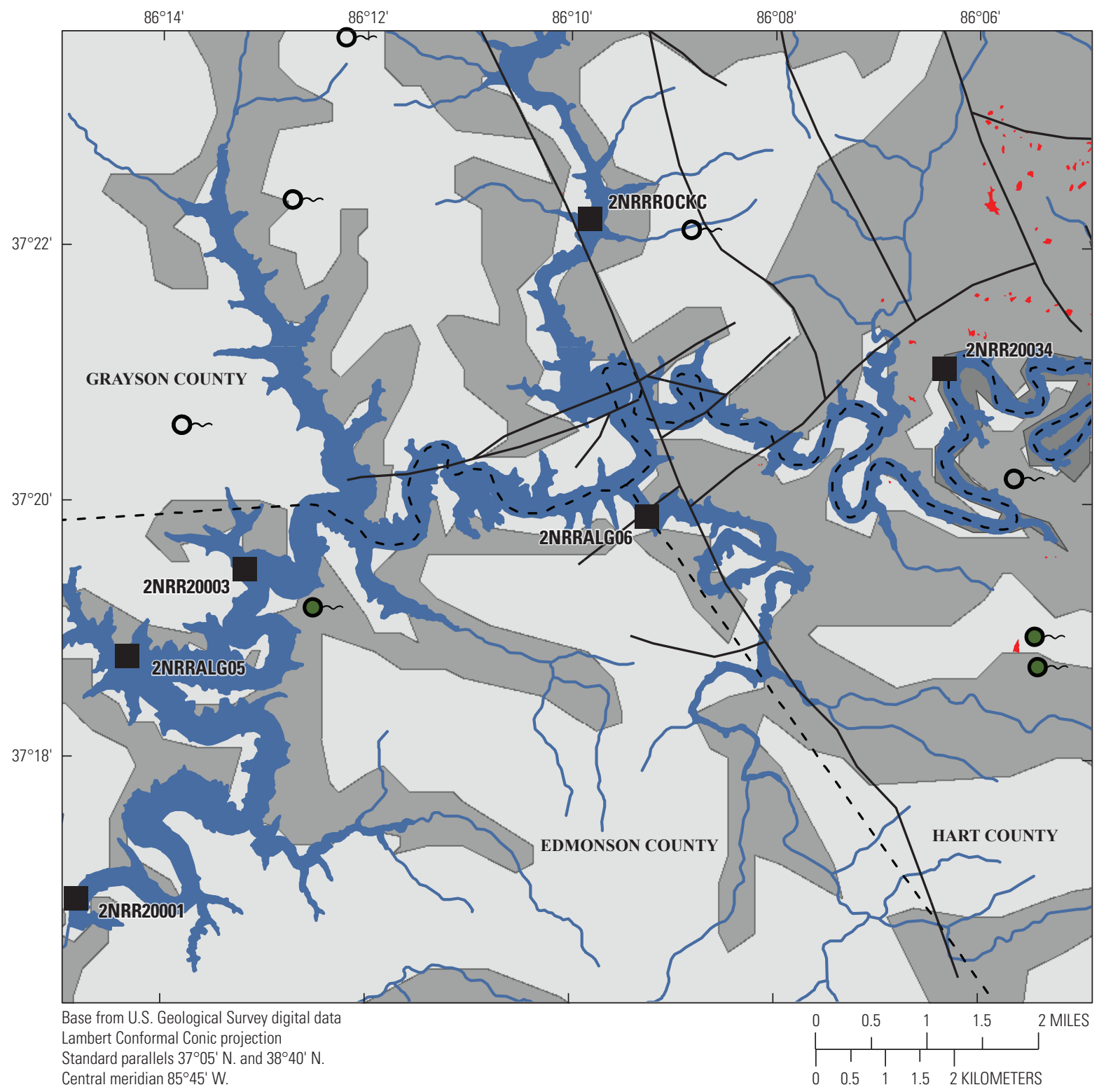

Central meridian $85^{\circ} 45^{\prime} \mathrm{W}$. and $38^{\circ} 40^{\prime} \mathrm{N}$.

EXPLANATION

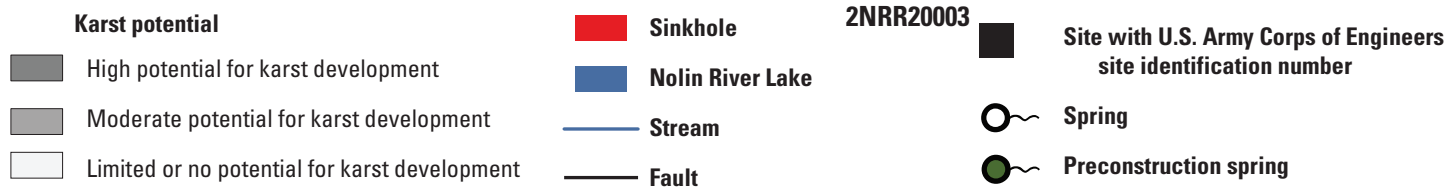

Figure 5. Faults and karst features at Nolin River Lake.

\section{Faults}

Faults were examined as a potential mechanism for preferential flow of groundwater into Nolin River Lake. Several faults pass through the northeast end of the reservoir (fig. 5). The faults are likely part of the Rough Creek fault system, a series of high-angle normal faults with total displacement of about $300 \mathrm{ft}$ that can be as much as $3,000 \mathrm{ft}$ (McDowell, 1986). One consequence of faulting is that rocks with varying hydraulic properties and resistance to weathering may become juxtaposed (McDowell, 1986). Vertical displacement at Nolin River Lake is generally less than $100 \mathrm{ft}$ (Gildersleeve, 1971).

A second consequence of faulting is that the fault zone that marks the actual site of rock rupture may become a zone of enhanced permeability if horizontal displacement causes a gap or is filled with crushed rock. In general, faults in western 
Kentucky are tight but they are potential zones of preferential flow because fractures in limestones can be sites of enhanced dissolution (Ennis Beck, Kentucky Geological Survey, written commun., February 12, 2018).

The longest fault at Nolin River Lake crosses near the northeast end of the reservoir and is nearly coincident with the eastern boundary of Hart County (fig. 5). The Dog Creek and Rock Creek Arms of the reservoir follow the same northwestsoutheast trend as this fault. North of Nolin River Lake, running parallel to the Rock Creek Arm of the reservoir, the western side of the fault is the upthrown block. South of the reservoir and running parallel to the Dog Creek Arm, the western side of the fault is the downthrown side (fig. 5). The vertical displacement of the fault raised the Hardinsburg Sandstone and Haney Limestone Member to land surface and put those units in contact with the reservoir at Dog Creek Arm, the eastern end of the reservoir, and the Nolin River. A geologic cross section presented by Gildersleeve (1971) shows the vertical displacement across the fault and the separation of limestone bedrock east of the fault from Pennsylvanian age siliciclastic rocks that occur at land surface west of the fault and surrounding most of the reservoir.

A second series of faults near the northeast end of the reservoir have an orientation that is approximately 90 degrees to the first series just described (fig. 5). The orientation of those faults is northeast-southwest and large parts of the main reservoir body follow that trend (fig. 5). These faults could potentially connect karst areas to the east with the reservoir.

Four of the sites sampled for water quality and reconnoitered with the AUV are near faults mapped near the east end of the reservoir. Site 2NRRROCKC is less than 0.2 mi northeast of the longest northwest-southeast oriented fault. Site 2NRRALG06 is approximately $0.3 \mathrm{mi}$ southwest of the longest northwestsoutheast oriented fault. Site 2NRR20003 is about $1 \mathrm{mi}$ from the westernmost terminus of a northeast-southwest oriented fault. Site 2NRR20034 is about $0.5 \mathrm{mi}$ southwest of a northeastsouthwest oriented fault. Sites 2NRRALG05 and 2NRR20001, positioned near the western end of the reservoir, are probably less likely to be affected by fault modifications to the hydrogeology (fig. 5).

\section{Karst Features}

Karst features near Nolin River Lake, Nolin River, and tributaries to the reservoir have been mapped by the USGS and the Kentucky Geological Survey (fig. 5). The Kentucky Geological Survey's online tools (https://kgs.uky.edu/kgsmap/ kgsgeoserver/viewer.asp) indicate that four springs are within $1 \mathrm{mi}$ of the north side of Nolin River Lake and one spring is within $1 \mathrm{mi}$ of the south side; the discharge rates of those springs are unknown. Numerous sinkholes and springs exist east of the reservoir and along the Nolin River, in Hart County, but few exist west of the reservoir. In general, sinkholes are east of the longest northwest-southeast trending fault zone that passes through the eastern part of the reservoir (fig. 5).
Springs were identified prior to the construction of Nolin River Lake (fig. 5) on unpublished maps residing in the Louisville, Kentucky, office of the USGS. Discharge was measured when the springs were mapped but the date of the measurement was not listed. Flow rates of springs likely vary by season and weather history, and discharge from the springs would likely be specific to those conditions. The preconstruction maps show one spring near the shoreline of Nolin River, two springs about $1 \mathrm{mi}$ southeast of the eastern end of the reservoir, and a fourth spring was immediately upstream from the reservoir and adjacent to the Nolin River. Measured discharge rates ranged from 0 (dry) to 400 gallons per minute. No springs were identified in the area that forms the bottom of the reservoir.

Ray and Currens (1998) and Paylor and Currens (2001) classified most of the area surrounding Nolin River Lake as an 'area of limited karst ground-water basin development'. Limited areas along the reservoir's shoreline, adjacent to Long Fall Creek Arm, Rock Creek Arm and Brier Creek Arm, are identified as areas of 'potential karst ground-water basin development' because limestone bedrock outcrops along the shoreline (fig. 5). Eight perennial underflow springs were identified along the Nolin River (Ray and Currens, 1998) and several karst features, which included karst windows, sinking creeks, stream sinks, and swallets (Monroe, 1899). Those features are mostly concentrated about 45 river miles upstream from where the Nolin River meets the reservoir property boundary. No springs or other karst features were identified beneath the reservoir or on tributaries adjacent to the reservoir that might supply water to the reservoir (Ray and Currens, 1998). None of the mapped springs are near to the sites sampled for water quality.

\section{Methods}

This section describes the methods used to collect onsite water-quality field parameter distributions using the AUV and discrete water-quality and phytoplankton samples. Discrete water-quality samples were collected and processed according to standard field methods (U.S. Geological Survey, variously dated).

\section{Integrated Synoptic Surveys}

Integrated synoptic surveys of onsite water-quality parameters were completed using an EcoMapper AUV with a manned boat at six sites on Nolin River Lake from August 15 to 19, 2016. For the purpose of simplicity, hereafter the EcoMapper AUV will be referred to as the EcoMapper. An EcoMapper is an instrument capable of collecting high-resolution (spatial and temporal) water-quality, water-velocity, bathymetry, and sonarimagery data. For this study, the EcoMapper was used to produce spatial distribution surveys of onsite water-quality parameters that included water temperature, $\mathrm{DO}, \mathrm{pH}, \mathrm{SC}$, turbidity, total chlorophyll as fluorescence, and phycocyanin as fluorescence 
Table 2. Manufacturer's specifications for the water-quality sensors aboard the autonomous underwater vehicle.

$\left[{ }^{\circ} \mathrm{C}\right.$, degree Celsius; --, not specified; $\mathrm{mS} / \mathrm{cm}$, millisiemens per centimeter at 25 degrees Celsius; \%, percent; $\mathrm{mg} / \mathrm{L}$, milligram per liter; $\mathrm{NTU}$, nephelometric turbidity unit; $\mu \mathrm{g} / \mathrm{L}$, microgram per liter; $R^{2}$, coefficient of determination; >, greater than; cells/mL, cells per milliliter; ft, foot]

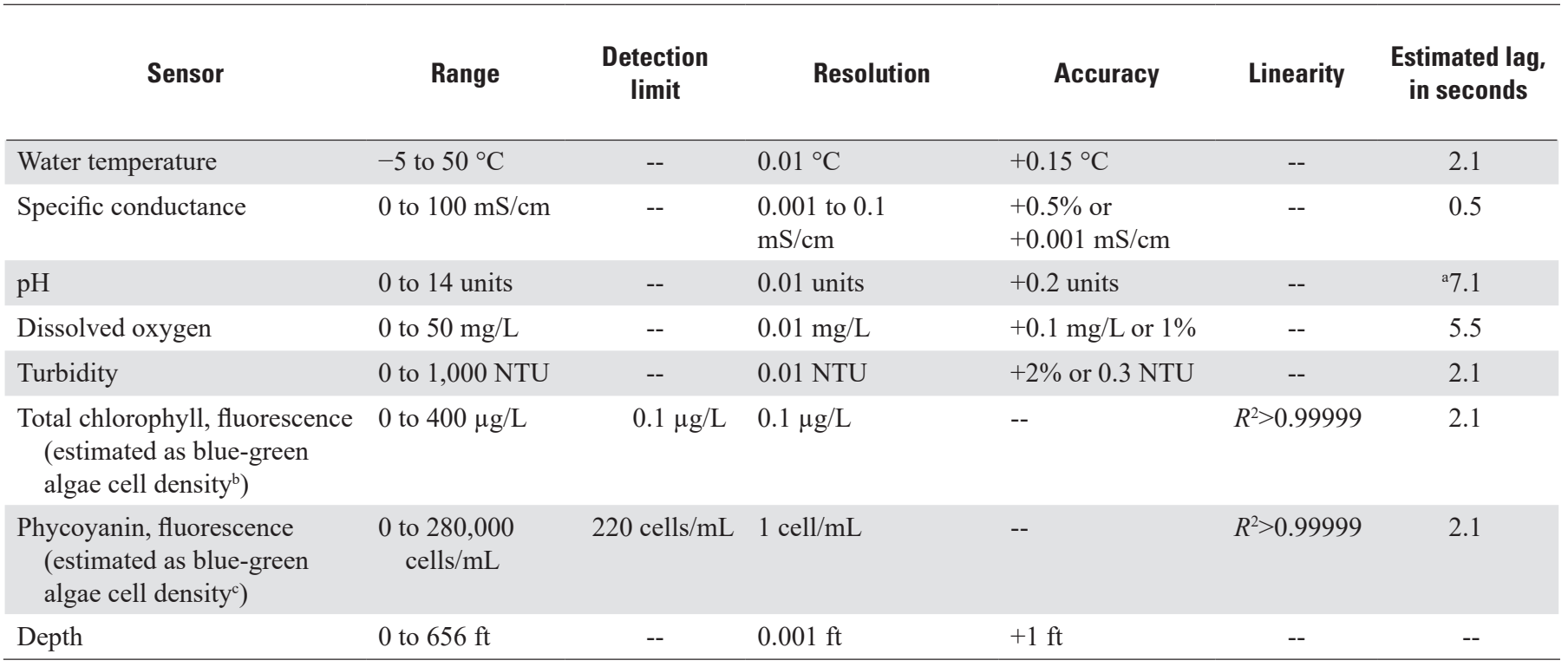

${ }^{\mathrm{a}}$ Can vary with age of sensor.

${ }^{b}$ Determined from cultures of Isochrysis sp. and chlorophyll $a$ concentration determined from extractions.

'Estimated from cultures of Microcystis aeruginosa.

(table 2). EcoMapper sensors estimate total chlorophyll and blue-green algae (cyanobacteria) concentrations using in vivo fluorometry of chlorophyll and phycocyanin (pigment present in freshwater cyanobacteria algae). Chlorophyll and phycocyanin are measured with the probes on the EcoMapper as relative fluorescence units, which is converted to concentrations using a calibrated relation between fluorescence and concentration (YSI Incorporated, 2012). The water-quality sensors on the EcoMapper were calibrated following procedures outlined in Wagner and others (2006) and by the sensor manufacturer. Water-quality sensors were calibrated before deployment.

The EcoMapper was programmed to collect data along a series of parallel lines spaced $25 \mathrm{ft}$ apart in a lawnmower-like pattern at each site (fig. 6). Each set of lines is called a mission. The EcoMapper would surface on each end of a line to acquire a global positioning system (GPS) signal, turn around, and move to the next line. The underwater portion of the lines was set at a specific depth from surface, which was predetermined so that the EcoMapper would complete a mission above, within, and below the thermocline at each site. The depth of the thermocline was determined before each mission using a sonde that was manually lowered near the center of each mission area. These specified depths for each site are listed in table 3 . Constant depth was the primary method used in completing the surveys and several depth layers were surveyed that varied by site $(5,10,15$, and $25 \mathrm{ft}$ ) (table 3$)$. A manned boat was used to deploy and recover the EcoMapper and to collect independent water-quality data. The EcoMapper was not maneuvered near the reservoir bottom or shoreline where potential obstacles that could trap the vehicle were suspected. Transects were not repeated because of logistics.

\section{Discrete Data Collection and Analysis Methods}

Depth profiles of onsite parameters, which include water temperature, $\mathrm{DO}, \mathrm{pH}, \mathrm{SC}$, turbidity, and total algae concentration, were obtained at each reservoir site using a multiparameter, water-quality sonde calibrated according to USGS methods (Wagner and others, 2006). Depth-profile measurements were taken at $1 \mathrm{ft}$ and $5 \mathrm{ft}$ below the water surface and then at intervals of $5 \mathrm{ft}$ until reaching the top of the hypolimnion zone (generally about $15-20 \mathrm{ft}$ below the water surface). Depth profiles were collected near the center of the area surveyed with the EcoMapper.

Discrete water-quality samples were collected at the same six sites where profiles of onsite parameters were measured. Discrete water-quality samples were collected $3 \mathrm{ft}$ below the water surface at each site using a vertically suspended 3.0-liter acrylic Kemmerer bottle (U.S. Geological Survey, variously dated). Discrete water-quality samples were collected following the synoptic AUV survey at each site. Water samples were analyzed for nutrients, chlorophyll $a$, and pheophytin $a$ by the USGS National Water Quality Laboratory in Denver, 

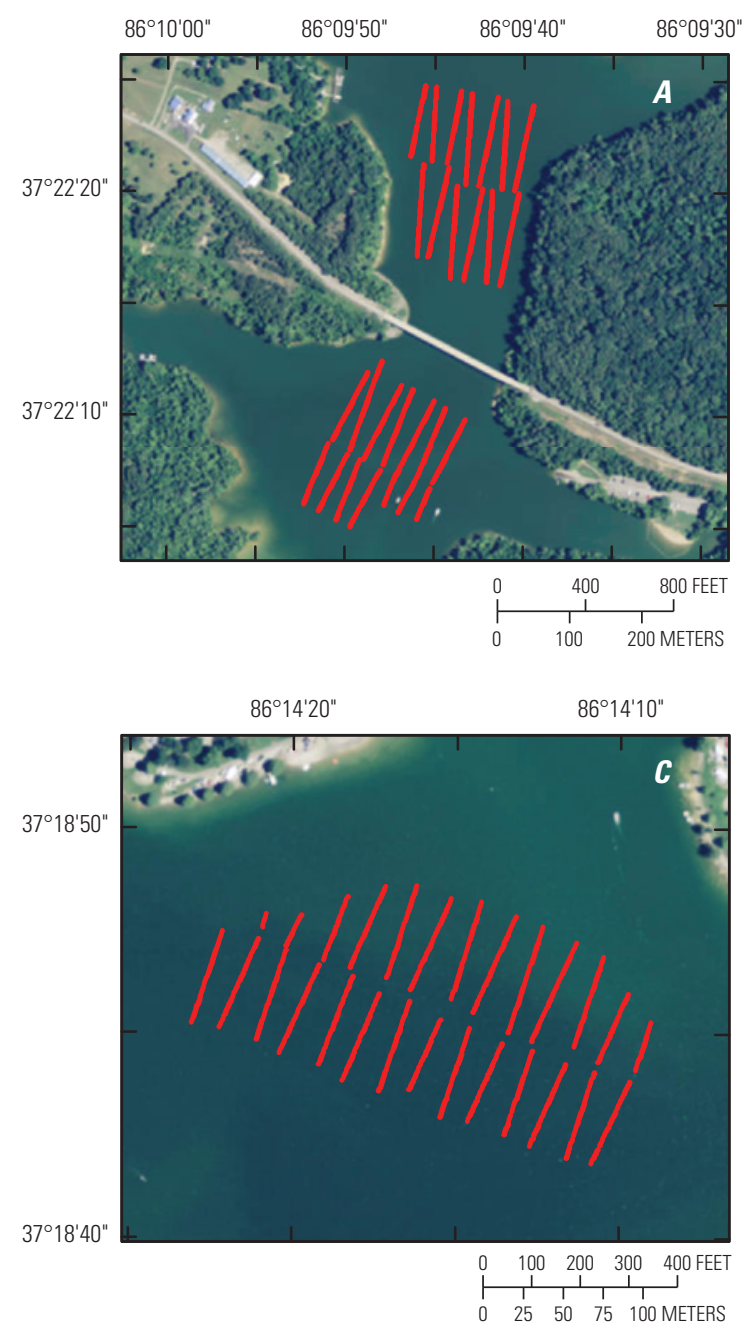

$86^{\circ} 14^{\prime} 50^{\prime \prime}$

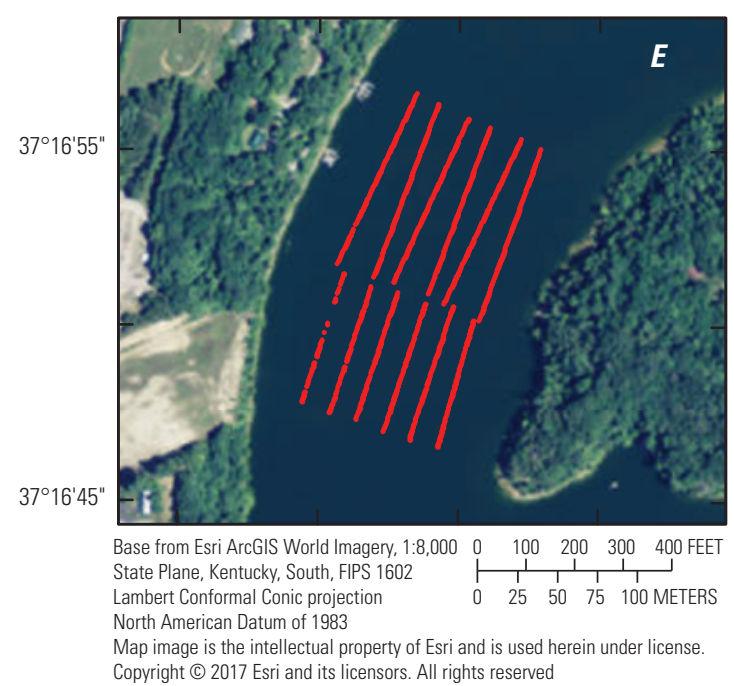

$86^{\circ} 09^{\prime} 20^{\prime \prime}$

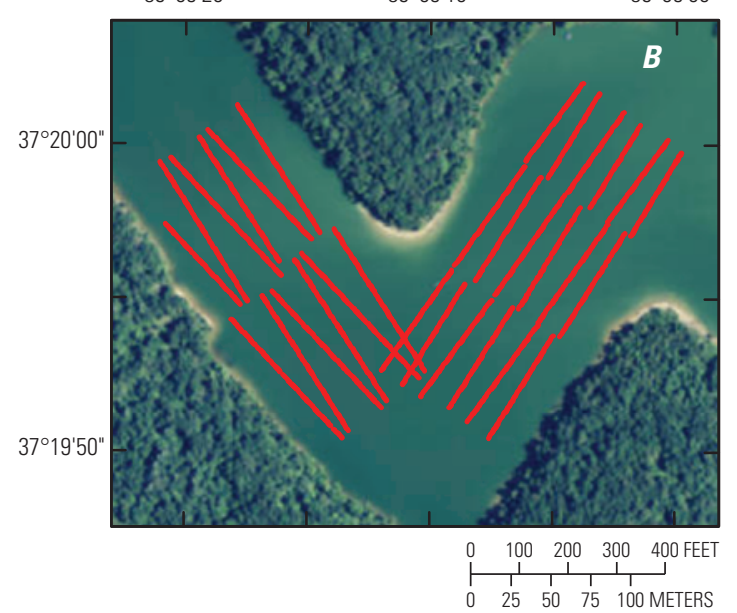

$86^{\circ} 13^{\prime} 15^{\prime \prime}$

$86^{\circ} 13^{\prime} 05^{\prime \prime}$

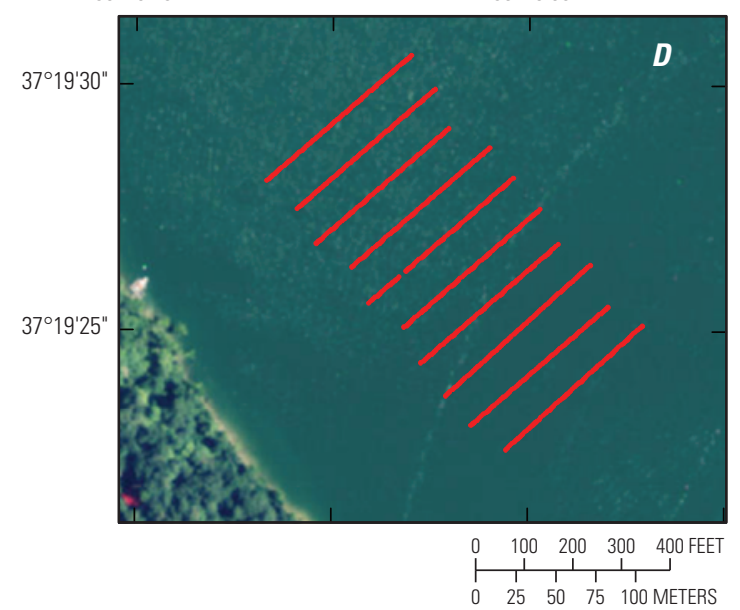

$86^{\circ} 06^{\prime} 20^{\prime \prime}$

$86^{\circ} 06^{\prime} 15^{\prime \prime}$

$86^{\circ} 06^{\prime} 10^{\prime \prime}$

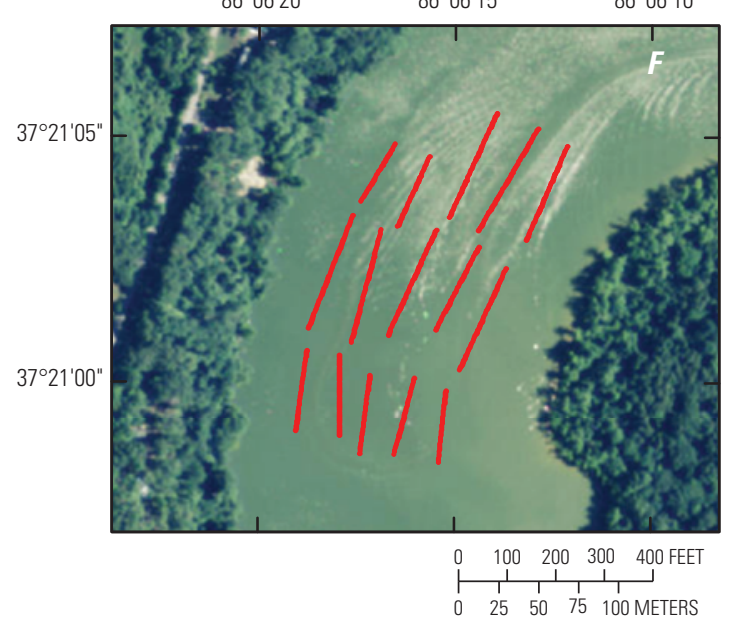

\section{EXPLANATION}

- Autonomous underwater vehicle path

Figure 6. Synoptic survey field with designated survey lines for sites on Nolin River Lake, August 15-19, 2016.

$A$, 2NRRROCKC; $B$, 2NRRALG06; C, 2NRRALG05; $D$, 2NRR20003; E, 2NRR20001; and $F$, 2NRR20034. 
Table 3. Sampling locations and depths at Nolin River Lake, Kentucky, August 15-19, 2016.

[USACE, U.S. Army Corps of Engineers; USGS, U.S. Geological Survey; NAD 83, North American Datum of 1983; ${ }^{\circ}$, degree]

\begin{tabular}{lccccl}
\hline USACE site number & USGS site number & Sampling date & Latitude (NAD 83) & Longitude (NAD 83) & $\begin{array}{c}\text { Sample depth } \\
\text { (foot) }\end{array}$ \\
\hline 2NRRROCKC & 372207086094500 & $8 / 15 / 2016$ & $37.369939^{\circ}$ & $-86.162492^{\circ}$ & $5,10,15$ \\
2NRRALG06 & 371954086091000 & $8 / 16 / 2016$ & $37.331169^{\circ}$ & $-86.152991^{\circ}$ & 5,15 \\
2NRRALG05 & 371852086141300 & $8 / 17 / 2016$ & $37.312719^{\circ}$ & $-86.237702^{\circ}$ & $5,15,25$ \\
2NRR20003 & 371927086131300 & $8 / 17 / 2016$ & $37.324038^{\circ}$ & $-86.218585^{\circ}$ & $5,15,25$ \\
2NRR20001 & 03310900 & $8 / 18 / 2016$ & $37.281011^{\circ}$ & $-86.246238^{\circ}$ & $5,15,25$ \\
2NRR20034 & 372108086061500 & $8 / 19 / 2016$ & $37.350581^{\circ}$ & $-86.104564^{\circ}$ & Surface, 5, 10, 15 \\
\hline
\end{tabular}

Colorado. Samples collected for nutrient analysis were filtered through a 0.45 -micrometer filter. Nutrients analyzed included ammonia as nitrogen, nitrite as nitrogen, nitrate plus nitrite as nitrogen, total nitrogen as nitrogen, total phosphorus as phosphorus, and orthophosphate as phosphorus (Fishman, 1993; Patton and Kryskalla, 2003; U.S. Environmental Protection Agency, 1993; and Patton and Kryskalla, 2011). Samples for chlorophyll $a$, and pheophytin $a$ (pigment degradation product of chlorophyll $a$ ) were collected on 0.47 -micron glass-fiber filters and analyzed according to standard methods and EPA method 445.0, respectively (Arar and Collins, 1997). Field blanks and replicate samples were not collected.

Whole-water samples were collected for phytoplankton community composition analysis, abundance (cells per liter), and biovolume (micrometers cubed per milliliter). Samples were preserved in Lugol's iodine and shipped to BSA Environmental Services, Inc., in Beachwood, Ohio, for analysis using the membrane-filtration technique (McNabb, 1960). The enumeration method used for phytoplankton abundance follows the method described in Lund and others (1958). Briefly, a minimum of 400 natural units (colonies, filaments, and unicells) were counted from each sample. Biovolume was calculated by using mean measured cell dimensions as described in Hillebrand and others (1999).

\section{Autonomous Underwater Vehicle Data Processing}

The EcoMapper AUV outputs the water-quality data to a semicolon-delimited American Standard Code for Information Interchange (ASCII) text file (log file) that includes a time and location (latitude, longitude, and depth) tag for each recorded measurement. Each mission has a separate log file. These output files were downloaded from the instrument and then processed through VectorMap software to apply a correction for underwater drift (VectorMap, 2015). This correction assumes a linear connection between the last surface point before the
EcoMapper dives underwater and the first surface point when the EcoMapper surfaces again. Underwater drift was minimal at all sites. Custom matrix laboratory (MATLAB) scripts were used to load the EcoMapper output files, screen spikes in the data, correct for lag in sensor response time, and interpolate to fill in the screened-out data spikes. In some cases, a specific lag issue typical with the $\mathrm{pH}$ and DO sensors was corrected by applying the value at the end of each line (the equilibrium value) to prior readings where the sensors had not yet reached equilibrium. The processed data were then saved to a commaseparated value (.csv) file.

For a variety of reasons (obstructions in the water, other boat traffic, safety, and among others) at some sites, the data for a given depth were collected in multiple missions. If applicable, all pieces of a layer were combined into a single .csv file. Then, all processed data were screened to remove the surface, diving, and rising portions of each mission, resulting in final .csv files with data at only the specified depths for each site. These data files are available in ScienceBase at https://doi.org/10.5066/F798857D (Crain and others, 2019) and the corresponding metadata contain additional documentation.

An aeronautical reconnaissance coverage geographic information system (ArcGIS) shapefile was created from each .csv file. Because of the way the EcoMapper operates and the depth screening process, sometimes a few points remained per layer that were discontiguous from the other data points. These discontiguous points were manually deleted and the shapefile resaved. A kriging interpolation method (part of the Spatial Analyst tools in ArcMap), was used to generate the raster coverages shown in the figures in this report. The kriging interpolation method is a useful visualization technique to see spatial variations in the water-quality parameters within a layer.

To facilitate comparisons between the EcoMapper onsite water-quality measurements and the discrete data from a vertical profile, a MATLAB script was used to calculate summary statistics on the processed .csv files for each water-quality parameter (table 4). Additional details about the data-processing routines, calibration procedures for the AUV, instrument operations, and handling of data files are in Jackson (2013). 
Table 4. Summary statistics of water-quality parameters at Nolin River Lake, Kentucky, August 15-19, 2016.

[USACE, U.S. Army Corps of Engineers; ft, foot; AUV, autonomous underwater vehicle; ${ }^{\circ} \mathrm{C}$, degrees Celsius; --, no measurement; mg/L, milligram per liter; $\mathrm{mS} / \mathrm{cm}$, millisiemens per centimeter at 25 degrees Celsius; FNU, formazin nephelometric unit; <, less than; $\mu \mathrm{g} / \mathrm{L}$, microgram per liter; cells $/ \mathrm{mL}$, cells per milliliter]

\begin{tabular}{|c|c|c|c|c|c|}
\hline Water-quality parameter & Layer & $\begin{array}{l}\text { Depth } \\
\text { (foot) }\end{array}$ & Minimum & Maximum & Mean \\
\hline \multicolumn{6}{|c|}{ USACE site 2NRRROCKC } \\
\hline \multirow[t]{4}{*}{ Water temperature, in ${ }^{\circ} \mathrm{C}$} & Surface & & -- & -- & -- \\
\hline & 2 & 10 & 29.7 & 29.9 & 29.8 \\
\hline & 3 & 15 & 28.3 & 29.9 & 29.5 \\
\hline & 4 & 25 & -- & -- & -- \\
\hline \multirow[t]{3}{*}{ Dissolved oxygen, in $\mathrm{mg} / \mathrm{L}$} & Surface & & -- & -- & -- \\
\hline & 1 & 5 & 7.2 & 8.7 & 8.0 \\
\hline & 4 & 25 & -- & -- & -- \\
\hline \multirow[t]{5}{*}{$\mathrm{pH}$, in standard units } & Surface & & -- & -- & -- \\
\hline & 1 & 5 & 8.4 & 8.8 & 8.6 \\
\hline & 2 & 10 & 8.0 & 8.7 & 8.3 \\
\hline & 3 & 15 & 7.3 & 8.5 & 7.9 \\
\hline & 4 & 25 & -- & -- & -- \\
\hline \multirow[t]{3}{*}{ Specific conductance, in $\mathrm{mS} / \mathrm{cm}$} & Surface & & -- & -- & -- \\
\hline & 1 & 5 & 0.195 & 0.198 & 0.197 \\
\hline & 2 & 10 & 0.195 & 0.201 & 0.198 \\
\hline \multirow{2}{*}{ Turbidity, in FNU } & 3 & 15 & $<5$ & 31 & 12.6 \\
\hline & 4 & 25 & -- & -- & -- \\
\hline \multirow{5}{*}{$\begin{array}{l}\text { Total chlorophyll, fluorescence } \\
\text { (estimated as concentration } \\
\left.\text { in } \mu \mathrm{g} / \mathrm{L}^{1}\right)\end{array}$} & Surface & & -- & -- & -- \\
\hline & 1 & 5 & $<1$ & 22.1 & 10.5 \\
\hline & 2 & 10 & $<1$ & 19.6 & 9.0 \\
\hline & 3 & 15 & $<1$ & 17.8 & 7.8 \\
\hline & 4 & 25 & -- & -- & -- \\
\hline \multirow{5}{*}{$\begin{array}{l}\text { Phycocyanin, fluorescence (estimated } \\
\text { as blue-green algae cell density in } \\
\text { cells } / \mathrm{mL}^{2} \text { ) }\end{array}$} & Surface & & -- & -- & -- \\
\hline & 1 & 5 & 1,831 & 10,104 & 6,273 \\
\hline & 2 & 10 & 5,302 & 11,829 & 8,469 \\
\hline & 3 & 15 & 2,055 & 11,094 & 7,405 \\
\hline & 4 & 25 & -- & -- & -- \\
\hline
\end{tabular}


Table 4. Summary statistics of water-quality parameters at Nolin River Lake, Kentucky, August 15-19, 2016._Continued

[USACE, U.S. Army Corps of Engineers; ft, foot; AUV, autonomous underwater vehicle; ${ }^{\circ} \mathrm{C}$, degrees Celsius; --, no measurement; mg/L, milligram per liter; $\mathrm{mS} / \mathrm{cm}$, millisiemens per centimeter at 25 degrees Celsius; FNU, formazin nephelometric unit; <, less than; $\mu \mathrm{g} / \mathrm{L}$, microgram per liter; cells $/ \mathrm{mL}$, cells per milliliter]

\begin{tabular}{|c|c|c|c|c|c|}
\hline Water-quality parameter & Layer & $\begin{array}{l}\text { Depth } \\
\text { (foot) }\end{array}$ & Minimum & Maximum & Mean \\
\hline \multicolumn{6}{|c|}{ USACE site 2NRRALG06 } \\
\hline \multirow[t]{4}{*}{ Water temperature, in ${ }^{\circ} \mathrm{C}$} & Surface & & -- & -- & -- \\
\hline & 2 & 10 & -- & -- & -- \\
\hline & 3 & 15 & 27.8 & 28.8 & 28.3 \\
\hline & 4 & 25 & -- & -- & -- \\
\hline \multirow[t]{2}{*}{ Dissolved oxygen, in $\mathrm{mg} / \mathrm{L}$} & Surface & & -- & -- & -- \\
\hline & 4 & 25 & -- & -- & -- \\
\hline \multirow[t]{5}{*}{$\mathrm{pH}$, in standard units } & Surface & & -- & -- & -- \\
\hline & 1 & 5 & 8.5 & 8.8 & 8.6 \\
\hline & 2 & 10 & -- & -- & -- \\
\hline & 3 & 15 & 7.3 & 8.0 & 7.4 \\
\hline & 4 & 25 & -- & -- & -- \\
\hline \multirow[t]{3}{*}{ Specific conductance, in $\mathrm{mS} / \mathrm{cm}$} & Surface & & -- & -- & -- \\
\hline & 1 & 5 & 0.207 & 0.212 & 0.208 \\
\hline & 2 & 10 & -- & -- & -- \\
\hline \multirow{2}{*}{ Turbidity, in FNU } & 3 & 15 & $<5$ & 5.1 & $<5$ \\
\hline & 4 & 25 & -- & -- & -- \\
\hline \multirow{5}{*}{$\begin{array}{l}\text { Total chlorophyll, fluorescence } \\
\text { (estimated as concentration } \\
\left.\text { in } \mu \mathrm{g} / \mathrm{L}^{1}\right)\end{array}$} & Surface & & -- & -- & -- \\
\hline & 1 & 5 & $<1$ & 21.3 & 8.7 \\
\hline & 2 & 10 & -- & -- & -- \\
\hline & 3 & 15 & 1.8 & 24.2 & 11.5 \\
\hline & 4 & 25 & -- & -- & -- \\
\hline \multirow{5}{*}{$\begin{array}{l}\text { Phycocyanin, fluorescence (estimated } \\
\text { as blue-green algae cell density in } \\
\text { cells } / \mathrm{mL}^{2} \text { ) }\end{array}$} & Surface & & -- & -- & -- \\
\hline & 1 & 5 & 1,090 & 8,064 & 3,998 \\
\hline & 2 & 10 & -- & -- & -- \\
\hline & 3 & 15 & 5,631 & 16,203 & 11,537 \\
\hline & 4 & 25 & -- & -- & -- \\
\hline
\end{tabular}


Table 4. Summary statistics of water-quality parameters at Nolin River Lake, Kentucky, August 15-19, 2016.—Continued

[USACE, U.S. Army Corps of Engineers; ft, foot; AUV, autonomous underwater vehicle; ${ }^{\circ} \mathrm{C}$, degrees Celsius; --, no measurement; mg/L, milligram per liter; $\mathrm{mS} / \mathrm{cm}$, millisiemens per centimeter at 25 degrees Celsius; FNU, formazin nephelometric unit; <, less than; $\mu \mathrm{g} / \mathrm{L}$, microgram per liter; cells $/ \mathrm{mL}$, cells per milliliter]

\begin{tabular}{|c|c|c|c|c|c|}
\hline Water-quality parameter & Layer & $\begin{array}{l}\text { Depth } \\
\text { (foot) }\end{array}$ & Minimum & Maximum & Mean \\
\hline \multicolumn{6}{|c|}{ USACE site 2NRRALG05 } \\
\hline \multirow[t]{4}{*}{ Water temperature, in ${ }^{\circ} \mathrm{C}$} & Surface & & -- & -- & -- \\
\hline & 2 & 10 & -- & -- & -- \\
\hline & 3 & 15 & 26.8 & 28.2 & 27.2 \\
\hline & 4 & 25 & 24.2 & 24.6 & 24.3 \\
\hline \multirow[t]{3}{*}{ Dissolved oxygen, in mg/L } & Surface & & -- & -- & -- \\
\hline & 1 & 5 & 7.9 & 8.2 & 8.1 \\
\hline & 4 & 25 & 0.8 & 4.4 & 0.9 \\
\hline \multirow[t]{5}{*}{$\mathrm{pH}$, in standard units } & Surface & & -- & -- & -- \\
\hline & 1 & 5 & 8.6 & 8.7 & 8.7 \\
\hline & 2 & 10 & -- & -- & -- \\
\hline & 3 & 15 & 7.5 & 8.2 & 7.6 \\
\hline & 4 & 25 & 7.4 & 8.0 & 7.5 \\
\hline \multirow[t]{3}{*}{ Specific conductance, in $\mathrm{mS} / \mathrm{cm}$} & Surface & & -- & -- & -- \\
\hline & 1 & 5 & 0.214 & 0.218 & 0.217 \\
\hline & 2 & 10 & -- & -- & -- \\
\hline \multirow{2}{*}{ Turbidity, in FNU } & 3 & 15 & $<5$ & $<5$ & $<5$ \\
\hline & 4 & 25 & $<5$ & 5.2 & $<5$ \\
\hline \multirow{5}{*}{$\begin{array}{l}\text { Total chlorophyll, fluorescence } \\
\text { (estimated as concentration } \\
\text { in } \mu \mathrm{g} / \mathrm{L}^{1} \text { ) }\end{array}$} & Surface & & -- & -- & -- \\
\hline & 1 & 5 & $<1$ & 17.7 & 8.2 \\
\hline & 2 & 10 & -- & -- & -- \\
\hline & 3 & 15 & $<1$ & 22.0 & 11.5 \\
\hline & 4 & 25 & $<1$ & 18.0 & 5.7 \\
\hline \multirow{5}{*}{$\begin{array}{l}\text { Phycocyanin, fluorescence (estimated } \\
\text { as blue-green algae cell density in } \\
\text { cells } / \mathrm{mL}^{2} \text { ) }\end{array}$} & Surface & & -- & -- & -- \\
\hline & 1 & 5 & 659 & 7,005 & 3,487 \\
\hline & 2 & 10 & -- & -- & -- \\
\hline & 3 & 15 & 3,274 & 15,766 & 12,073 \\
\hline & 4 & 25 & 123 & 4,027 & 1,541 \\
\hline
\end{tabular}


Table 4. Summary statistics of water-quality parameters at Nolin River Lake, Kentucky, August 15-19, 2016._Continued

[USACE, U.S. Army Corps of Engineers; ft, foot; AUV, autonomous underwater vehicle; ${ }^{\circ} \mathrm{C}$, degrees Celsius; --, no measurement; mg/L, milligram per liter; $\mathrm{mS} / \mathrm{cm}$, millisiemens per centimeter at 25 degrees Celsius; FNU, formazin nephelometric unit; <, less than; $\mu \mathrm{g} / \mathrm{L}$, microgram per liter; cells $/ \mathrm{mL}$, cells per milliliter]

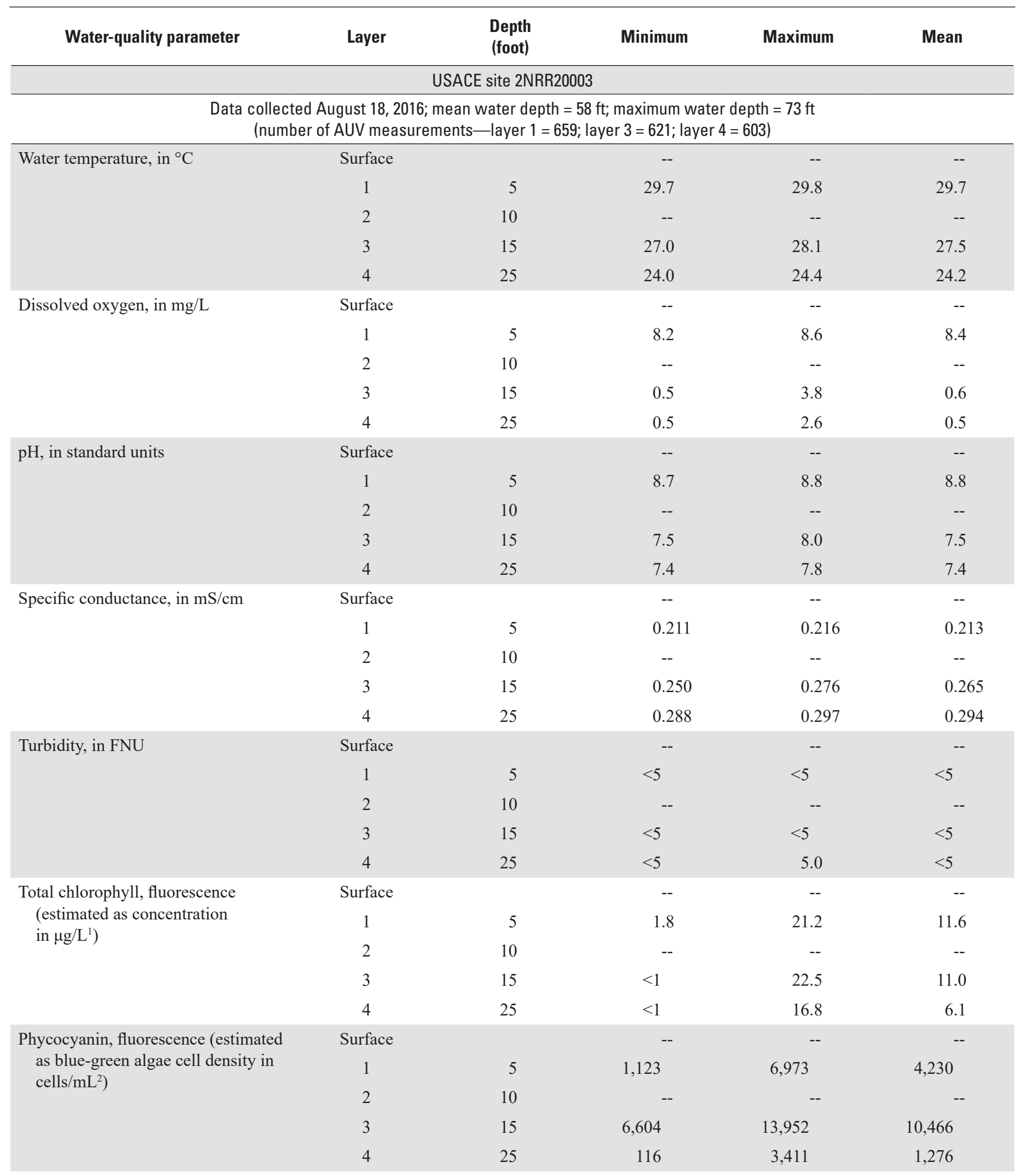


Table 4. Summary statistics of water-quality parameters at Nolin River Lake, Kentucky, August 15-19, 2016.—Continued

[USACE, U.S. Army Corps of Engineers; ft, foot; AUV, autonomous underwater vehicle; ${ }^{\circ} \mathrm{C}$, degrees Celsius; --, no measurement; mg/L, milligram per liter; $\mathrm{mS} / \mathrm{cm}$, millisiemens per centimeter at 25 degrees Celsius; FNU, formazin nephelometric unit; <, less than; $\mu \mathrm{g} / \mathrm{L}$, microgram per liter; cells $/ \mathrm{mL}$, cells per milliliter]

\begin{tabular}{|c|c|c|c|c|c|}
\hline Water-quality parameter & Layer & $\begin{array}{l}\text { Depth } \\
\text { (foot) }\end{array}$ & Minimum & Maximum & Mean \\
\hline \multicolumn{6}{|c|}{ USACE site 2NRR20001 } \\
\hline \multirow[t]{3}{*}{ Water temperature, in ${ }^{\circ} \mathrm{C}$} & Surface & & -- & -- & -- \\
\hline & 3 & 15 & -- & -- & -- \\
\hline & 4 & 25 & 24.1 & 24.4 & 24.2 \\
\hline \multirow[t]{3}{*}{ Dissolved oxygen, in mg/L } & Surface & & -- & -- & -- \\
\hline & 1 & 5 & 8.0 & 8.5 & 8.3 \\
\hline & 4 & 25 & 0.4 & 2.4 & 0.4 \\
\hline \multirow[t]{5}{*}{$\mathrm{pH}$, in standard units } & Surface & & -- & -- & -- \\
\hline & 1 & 5 & 8.6 & 8.7 & 8.7 \\
\hline & 2 & 10 & 8.6 & 8.7 & 8.7 \\
\hline & 3 & 15 & -- & -- & -- \\
\hline & 4 & 25 & 7.4 & 7.7 & 7.4 \\
\hline \multirow[t]{3}{*}{ Specific conductance, in $\mathrm{mS} / \mathrm{cm}$} & Surface & & -- & -- & -- \\
\hline & 1 & 5 & 0.229 & 0.232 & 0.230 \\
\hline & 2 & 10 & 0.229 & 0.231 & 0.230 \\
\hline \multirow{2}{*}{ Turbidity, in FNU } & 3 & 15 & -- & -- & -- \\
\hline & 4 & 25 & $<5$ & $<5$ & $<5$ \\
\hline \multirow{5}{*}{$\begin{array}{l}\text { Total chlorophyll, fluorescence } \\
\text { (estimated as concentration } \\
\left.\text { in } \mu \mathrm{g} / \mathrm{L}^{1}\right)\end{array}$} & Surface & & -- & -- & -- \\
\hline & 1 & 5 & $<1$ & 20.3 & 10.7 \\
\hline & 2 & 10 & 1.2 & 22.4 & 10.9 \\
\hline & 3 & 15 & -- & -- & -- \\
\hline & 4 & 25 & $<1$ & 17.2 & 8.5 \\
\hline \multirow{5}{*}{$\begin{array}{l}\text { Phycocyanin, fluorescence (estimated } \\
\text { as blue-green algae cell density in } \\
\text { cells } / \mathrm{mL}^{2} \text { ) }\end{array}$} & Surface & & -- & -- & -- \\
\hline & 1 & 5 & 5,282 & 10,596 & 7,902 \\
\hline & 2 & 10 & 5,285 & 10,569 & 8,156 \\
\hline & 3 & 15 & -- & -- & -- \\
\hline & 4 & 25 & 319 & 4,493 & 2,204 \\
\hline
\end{tabular}


Table 4. Summary statistics of water-quality parameters at Nolin River Lake, Kentucky, August 15-19, 2016._Continued

[USACE, U.S. Army Corps of Engineers; ft, foot; AUV, autonomous underwater vehicle; ${ }^{\circ} \mathrm{C}$, degrees Celsius; --, no measurement; mg/L, milligram per liter; $\mathrm{mS} / \mathrm{cm}$, millisiemens per centimeter at 25 degrees Celsius; FNU, formazin nephelometric unit; <, less than; $\mu \mathrm{g} / \mathrm{L}$, microgram per liter; cells $/ \mathrm{mL}$, cells per milliliter]

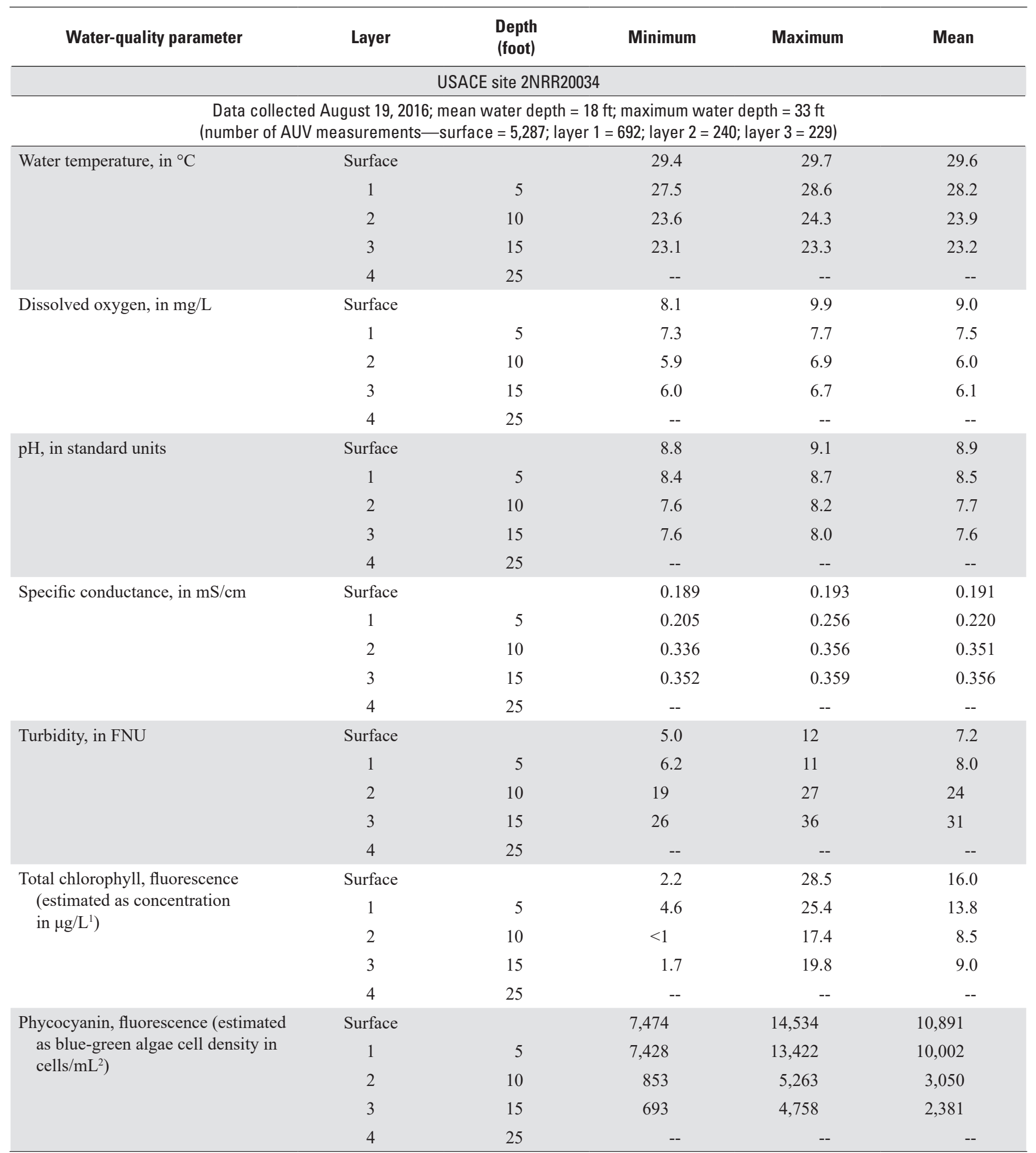

${ }^{1}$ Determined from cultures of Isochrysis sp. and chlorophyll $a$ concentration determined from extractions.

${ }^{2}$ Estimated from cultures of Microcystis aeruginosa. 


\section{Potential Interaction of Groundwater and Surface Water at Nolin River Lake}

The hydrogeological setting of Nolin River Lake includes mixed bedrock units with mixed lithologies, structural faults, and a few nearby karst springs. Northwest-southeast trending faults effectively separate the Nolin River Lake area from the karst plain to the east. Karst hydrogeology dominates the drainage in most of the basin that is upstream from the reservoir. Surface exposure of limestone occurs at the reservoir shoreline in the Long Fall Creek Arm and the Rock Creek Arm and may form the lakebed beneath unconsolidated deposits throughout most of the reservoir. A few springs were near Nolin River Lake, but none were mapped prior to reservoir construction where the current reservoir exists. The immature karst drainage system adjacent to the reservoir may be attributed to the presence of siliciclastic rocks that overlie the limestone and limit interaction with acidic infiltration. These observations indicate that groundwater is likely entering the reservoir primarily by intergranular flow and not likely discharging to the reservoir through karst features. The potential for preferential flow through fault zones is uncertain as the relation between the faults and permeability has not been studied.

The EcoMapper and discrete data were examined in the context of a hydrogeological characterization of Nolin River Lake developed from existing information. EcoMapper surveys were completed closest to the reservoir bottom at sites 2NRROCKC and 2NRR20034 (fig. 1) but likely too far above the bottom at the other sites to detect localized groundwater inflows through karst features or fault zones. In general, spatial distributions of onsite water-quality parameters were uniform within each measured reservoir layer at each site. Variability in water-quality data between successive layers was evident at each site and indicated thermal and water-quality parameter stratification.

The discrete sample concentrations of nutrients did exceed the 25th percentile of median concentrations of nitrate plus nitrite as nitrogen $(0.10 \mathrm{mg} / \mathrm{L})$, total nitrogen as nitrogen $(0.47 \mathrm{mg} / \mathrm{L})$, and total phosphorus as phosphorus $(0.016 \mathrm{mg} / \mathrm{L})$ as measured by EPA at other lakes and reservoirs in EPA level IV ecoregion 71a (U.S. Environmental Protection Agency, 2000). The concentrations of nutrients at the five reservoir sites located in EPA level IV ecoregion $72 \mathrm{~h}$ also exceeded the concentrations of nitrate plus nitrite as nitrogen $(0.005 \mathrm{mg} / \mathrm{L})$, total nitrogen as nitrogen $(0.61 \mathrm{mg} / \mathrm{L})$, and total phosphorus as phosphorus $(0.03 \mathrm{mg} / \mathrm{L})$ as measured by EPA at other lakes and reservoirs. The exception was the concentrations of total phosphorus as phosphorus at the reservoir sites in ecoregion $72 \mathrm{~h}$. The concentrations of total phosphorus as phosphorus did not exceed the 25th percentile of median concentrations measured by EPA $(0.03 \mathrm{mg} / \mathrm{L})$ in lakes and reservoirs (U.S. Environmental Protection Agency, 2000).

The concentrations of chlorophyll $a$ at the Nolin River Lake sites except site 2NRRROCKC $(8.45 \mathrm{mg} / \mathrm{L})$ exceeded the 25th percentile of median concentrations measured by EPA in level IV ecoregion 71a $(6.2 \mathrm{mg} / \mathrm{L})$ and level IV ecoregion $72 \mathrm{~h}(9.1 \mathrm{mg} / \mathrm{L})$ (U.S. Environmental Protection Agency, 2000). Among the sampled sites, site 2 NRR0034 had the highest concentrations of chlorophyll $a$ at 36.1 micrograms per liter $(\mu \mathrm{g} / \mathrm{L})$. Cyanobacteria dominated the phytoplankton community with greater than 90 percent of the total phytoplankton abundance determined in Nolin River Lake in August 2016.

\section{Reservoir Water-Quality Data during August 15-19, 2016}

This section discusses water-quality data measured using instruments aboard the AUV at six sites in Nolin River Lake and Nolin River during August 15-19, 2016. Results of the discrete water-quality data and phytoplankton community structure and abundance data collected following the surveys at each site also are presented (tables 5 and 6). All data from the synoptic surveys, including results for discrete water-quality samples and phytoplankton community structure and abundance data are in ScienceBase at https://doi.org/10.5066/F798857D (Crain and others, 2019).

\section{Water-Quality Data Measured with the Autonomous Underwater Vehicle}

Results of the data collected on August 15, 2016, at site 2NRRROCKC showed the distribution of mean water temperature to be somewhat uniform throughout the water column, with temperatures that ranged from $29.5^{\circ} \mathrm{C}$ in layer 3 ( $15 \mathrm{ft}$ below the surface) to $30.2^{\circ} \mathrm{C}$ in layer $1(5 \mathrm{ft}$ below the surface) (table 4). Within layer 1 ( $5 \mathrm{ft}$ below water surface) is an area just south of the KY-88 bridge where water temperatures were about $1{ }^{\circ} \mathrm{C}$ higher than the area north of the KY-88 bridge (fig. 7). The distribution of DO values showed a direct pattern to water temperature - that is, DO decreased as water temperature decreased. Mean values of DO ranged from 5.0 to $8.0 \mathrm{mg} / \mathrm{L}$, with the lowest measured mean DO value observed in layer 3 ( $15 \mathrm{ft}$ below water surface) (table 4). Mean values of $\mathrm{pH}$ ranged from 7.9 standard units to 8.6 standard units, with higher $\mathrm{pH}$ values measured south of the Highway 88 bridge. Values of $\mathrm{pH}$ greater than 8.5 standard units have been determined to cause the release of phosphorus from reservoir sediments (James and Barko, 1991); however, $\mathrm{pH}$ values greater than 8.5 generally occurred at shallower depths (table 4 ). The distribution of mean $\mathrm{SC}$ was uniform throughout the water column at site 2NRRROCKC, with values that ranged from 0.197 to 0.199 millisiemens per centimeter at $25^{\circ} \mathrm{C}(\mathrm{mS} / \mathrm{cm})$ (table 4). Mean turbidity values ranged from less than 5 to 12.6 formazin nephelometric units (FNU) with the highest mean value of turbidity observed in layer 3 (near bottom) and which corresponded to areas of low DO values (less than $5 \mathrm{mg} / \mathrm{L}$ ). Mean values of chlorophyll ranged from 7.8 to $10.5 \mu \mathrm{g} / \mathrm{L}$ and were not uniformly distributed (table 4). 
Table 5. Summary of nutrient, chlorophyll $a$, and pheophytin a concentrations in discrete-depth samples from Nolin River Lake, August 15-19, 2016.

[USACE, U.S. Army Corps of Engineers; USGS, U.S. Geological Survey; mg/L, milligram per liter; $\mu \mathrm{g} / \mathrm{L}$, microgram per liter; nd, no data available; $<$, less than]

\begin{tabular}{|c|c|c|c|c|c|c|c|c|c|c|c|}
\hline $\begin{array}{c}\text { USACE } \\
\text { site number }\end{array}$ & $\begin{array}{c}\text { USGS } \\
\text { site number }\end{array}$ & $\begin{array}{c}\text { Sample } \\
\text { date }\end{array}$ & $\begin{array}{l}\text { Sample } \\
\text { time }\end{array}$ & $\begin{array}{c}\text { Total nitrogen, } \\
\text { as nitrogen', } \\
\text { unfiltered } \\
\text { (mg/L) }\end{array}$ & $\begin{array}{c}\text { Ammonia, } \\
\text { as nitrogen', } \\
\text { filtered } \\
\text { (mg/L) }\end{array}$ & $\begin{array}{c}\text { Nitrate as } \\
\text { nitrogen', } \\
\text { filtered } \\
\text { (mg/L) }\end{array}$ & $\begin{array}{c}\text { Nitrate plus } \\
\text { nitrate as } \\
\text { nitrogen', } \\
\text { filtered (mg/L) }\end{array}$ & $\begin{array}{c}\text { Total } \\
\text { phosphorus as } \\
\text { phosphorus }{ }^{1} \text {, } \\
\text { filtered (mg/L) }\end{array}$ & $\begin{array}{l}\text { Orthophosphate } \\
\text { as phosphorus', } \\
\text { filtered } \\
\text { (mg/L) }\end{array}$ & $\begin{array}{c}\text { Chlorophyll } a^{1} \\
(\mu \mathrm{g} / \mathrm{L})\end{array}$ & $\begin{array}{c}\text { Pheophytin } a^{1} \\
(\mu \mathrm{g} / \mathrm{L})\end{array}$ \\
\hline 2NRRROCKC & 372207086094500 & $8 / 15 / 2016$ & 1620 & 0.769 & nd & $<0.001$ & $<0.04$ & 0.03 & $<0.004$ & 8.45 & 2.14 \\
\hline 2NRRALG06 & 371954086091000 & $8 / 16 / 2016$ & 1500 & 1.54 & nd & $<0.001$ & 0.049 & 0.03 & $<0.004$ & 9.29 & 2.53 \\
\hline 2NRRALG05 & 371852086141300 & $8 / 17 / 2016$ & 1300 & 0.723 & 0.678 & 0.014 & $<0.04$ & 0.02 & $<0.004$ & 11.1 & 2.45 \\
\hline 2NRR20003 & 371927086131300 & $8 / 17 / 2016$ & 1600 & 4.84 & nd & $<0.001$ & $<0.04$ & 0.03 & $<0.004$ & 13.9 & 3.5 \\
\hline 2NRR20001 & 03310900 & $8 / 18 / 2016$ & 1200 & 1.40 & nd & 0.013 & 0.087 & 0.02 & $<0.004$ & 17.9 & 3.06 \\
\hline 2NRR20034 & 372108086061500 & $8 / 19 / 2016$ & 0930 & 2.37 & 0.452 & 0.002 & 0.145 & 0.07 & $<0.004$ & 36.1 & 10.2 \\
\hline
\end{tabular}

${ }^{1}$ Discrete sample collected at a depth of 3 feet below the surface. 
Table 6. Cyanobacterial abundance in discrete water-quality samples collected at Nolin River Lake, August 15-19, 2016.

[USACE, U.S. Army Corps of Engineers; USGS, U.S. Geological Survey; cells/L, cells per liter; $\mu \mathrm{m}^{3} / \mathrm{mL}$, micrometers cubed per milliliter; spp., species; cf, compared with]

\begin{tabular}{|c|c|c|c|c|c|c|c|c|}
\hline $\begin{array}{l}\text { USACE site } \\
\text { number }\end{array}$ & USGS site number & Sample date & Sample time & Genus & Division & Tally & $\begin{array}{l}\text { Density } \\
\text { (cells/L) }\end{array}$ & $\begin{array}{c}\text { Total biovolume } \\
\left(\mu^{3} / \mathrm{L}\right)\end{array}$ \\
\hline 2NRRROCKC & 372207086094500 & $8 / 15 / 2016$ & 1620 & Achnanthidium catenatum & Bacillariophyta & 29 & $2,481,191$ & $152,000,232$ \\
\hline 2NRRROCKC & 372207086094500 & $8 / 15 / 2016$ & 1620 & Achnanthidium minutissimum & Bacillariophyta & 1 & 85,558 & $4,435,020$ \\
\hline 2NRRROCKC & 372207086094500 & $8 / 15 / 2016$ & 1620 & Cyclotella spp. & Bacillariophyta & 23 & $1,967,841$ & $115,915,296$ \\
\hline 2NRRROCKC & 372207086094500 & $8 / 15 / 2016$ & 1620 & Fragilaria tenera & Bacillariophyta & 6 & 513,350 & $101,602,277$ \\
\hline 2NRRROCKC & 372207086094500 & $8 / 15 / 2016$ & 1620 & Navicula spp. & Bacillariophyta & 2 & 171,117 & $28,222,855$ \\
\hline 2NRRROCKC & 372207086094500 & $8 / 15 / 2016$ & 1620 & Nitzschia spp. & Bacillariophyta & 1 & 7,264 & 348,662 \\
\hline 2NRRROCKC & 372207086094500 & $8 / 15 / 2016$ & 1620 & Chlamydomonas globosa & Chlorophyta & 11 & 941,141 & $88,700,401$ \\
\hline 2NRRROCKC & 372207086094500 & $8 / 15 / 2016$ & 1620 & Chlorella spp. & Chlorophyta & 24 & $2,053,399$ & $8,601,251$ \\
\hline 2NRRROCKC & 372207086094500 & $8 / 15 / 2016$ & 1620 & Coelastrum spp. & Chlorophyta & 13 & 5,200 & 340,342 \\
\hline 2NRRROCKC & 372207086094500 & $8 / 15 / 2016$ & 1620 & Cosmarium spp. & Chlorophyta & 1 & 85,558 & $174,175,332$ \\
\hline 2NRRROCKC & 372207086094500 & $8 / 15 / 2016$ & 1620 & Crucigenia spp. & Chlorophyta & 16 & $1,368,933$ & $61,601,974$ \\
\hline 2NRRROCKC & 372207086094500 & $8 / 15 / 2016$ & 1620 & Monoraphidium tortile & Chlorophyta & 1 & 85,558 & $2,508,698$ \\
\hline 2NRRROCKC & 372207086094500 & $8 / 15 / 2016$ & 1620 & Oocystis spp. & Chlorophyta & 4 & 342,233 & $22,936,669$ \\
\hline 2NRRROCKC & 372207086094500 & $8 / 15 / 2016$ & 1620 & Scenedesmus spp. & Chlorophyta & 2 & 171,117 & $6,450,938$ \\
\hline 2NRRROCKC & 372207086094500 & $8 / 15 / 2016$ & 1620 & Sphaerocystis planctonica & Chlorophyta & 8 & 684,466 & $77,411,259$ \\
\hline 2NRRROCKC & 372207086094500 & $8 / 15 / 2016$ & 1620 & Staurastrum spp. & Chlorophyta & 1 & 85,558 & $388,131,450$ \\
\hline 2NRRROCKC & 372207086094500 & $8 / 15 / 2016$ & 1620 & Tetraedron minimum & Chlorophyta & 1 & 400 & 43,200 \\
\hline 2NRRROCKC & 372207086094500 & $8 / 15 / 2016$ & 1620 & Tetrastrum spp. & Chlorophyta & 8 & 684,466 & $77,411,259$ \\
\hline 2NRRROCKC & 372207086094500 & $8 / 15 / 2016$ & 1620 & Cryptomonas erosa & Cryptophyta & 1 & 7,264 & $5,237,163$ \\
\hline 2NRRROCKC & 372207086094500 & $8 / 15 / 2016$ & 1620 & Plagioselmis spp. & Cryptophyta & 9 & 770,025 & $65,315,750$ \\
\hline 2NRRROCKC & 372207086094500 & $8 / 15 / 2016$ & 1620 & Aphanocapsa spp. & Cyanobacteria & 37 & $3,165,657$ & $1,657,533$ \\
\hline 2NRRROCKC & 372207086094500 & $8 / 15 / 2016$ & 1620 & Chroococcus microscopicus & Cyanobacteria & 637 & $54,500,636$ & $14,610,658$ \\
\hline 2NRRROCKC & 372207086094500 & $8 / 15 / 2016$ & 1620 & Chroococcus minimus & Cyanobacteria & 26 & $2,224,516$ & $9,318,022$ \\
\hline 2NRRROCKC & 372207086094500 & $8 / 15 / 2016$ & 1620 & cf. Cylindrospermopsis spp. & Cyanobacteria & 885 & $75,719,094$ & $475,756,695$ \\
\hline 2NRRROCKC & 372207086094500 & $8 / 15 / 2016$ & 1620 & cf. Planktolyngbya spp. & Cyanobacteria & 137 & $11,721,487$ & $18,412,053$ \\
\hline 2NRRROCKC & 372207086094500 & $8 / 15 / 2016$ & 1620 & Euglena spp. & Euglenophyta & 1 & 7,264 & $16,464,546$ \\
\hline 2NRRROCKC & 372207086094500 & $8 / 15 / 2016$ & 1620 & Trachelomonas volvocina & Euglenophyta & 1 & 7,264 & $1,901,657$ \\
\hline 2NRRROCKC & 372207086094500 & $8 / 15 / 2016$ & 1620 & Peridinium spp. & Pyrrophyta & 1 & 7,264 & $5,202,933$ \\
\hline
\end{tabular}


Table 6. Cyanobacterial abundance in discrete water-quality samples collected at Nolin River Lake, August 15-19, 2016.-Continued

[USACE, U.S. Army Corps of Engineers; USGS, U.S. Geological Survey; cells $/ \mathrm{L}$, cells per liter; $\mu \mathrm{m}^{3} / \mathrm{mL}$, micrometers cubed per milliliter; spp., species; cf, compared with]

\begin{tabular}{|c|c|c|c|c|c|c|c|c|}
\hline $\begin{array}{c}\text { USACE site } \\
\text { number }\end{array}$ & USGS site number & Sample date & Sample time & Genus & Division & Tally & $\begin{array}{c}\text { Density } \\
\text { (cells/L) }\end{array}$ & $\begin{array}{c}\text { Total biovolume } \\
\left(\mu \mathrm{m}^{3} / \mathrm{L}\right)\end{array}$ \\
\hline 2NRRALG06 & 371954086091000 & $8 / 16 / 2016$ & 1500 & Achnanthidium catenatum & Bacillariophyta & 49 & $4,192,357$ & $237,071,980$ \\
\hline 2NRRALG06 & 371954086091000 & $8 / 16 / 2016$ & 1500 & Cyclotella spp. & Bacillariophyta & 6 & 513,350 & $30,238,773$ \\
\hline 2NRRALG06 & 371954086091000 & $8 / 16 / 2016$ & 1500 & Fragilaria tenera & Bacillariophyta & 8 & 684,466 & $137,620,016$ \\
\hline 2NRRALG06 & 371954086091000 & $8 / 16 / 2016$ & 1500 & Navicula gregaria & Bacillariophyta & 8 & 684,466 & $217,719,165$ \\
\hline 2NRRALG06 & 371954086091000 & $8 / 16 / 2016$ & 1500 & Nitzschia spp. & Bacillariophyta & 2 & 171,117 & $9,753,646$ \\
\hline 2NRRALG06 & 371954086091000 & $8 / 16 / 2016$ & 1500 & Chlamydomonas spp. & Chlorophyta & 8 & 684,466 & $160,556,685$ \\
\hline 2NRRALG06 & 371954086091000 & $8 / 16 / 2016$ & 1500 & Chlorella spp. & Chlorophyta & 37 & $3,165,657$ & $13,260,262$ \\
\hline 2NRRALG06 & 371954086091000 & $8 / 16 / 2016$ & 1500 & Crucigenia spp. & Chlorophyta & 16 & 116,221 & $5,229,936$ \\
\hline 2NRRALG06 & 371954086091000 & $8 / 16 / 2016$ & 1500 & Oocystis spp. & Chlorophyta & 4 & 29,055 & $1,947,297$ \\
\hline 2NRRALG06 & 371954086091000 & $8 / 16 / 2016$ & 1500 & Scenedesmus spp. & Chlorophyta & 10 & 855,583 & $32,254,691$ \\
\hline 2NRRALG06 & 371954086091000 & $8 / 16 / 2016$ & 1500 & Sphaerocystis planctonica & Chlorophyta & 10 & 855,583 & $96,764,073$ \\
\hline 2NRRALG06 & 371954086091000 & $8 / 16 / 2016$ & 1500 & Tetraedron minimum & Chlorophyta & 4 & 1,600 & 172,802 \\
\hline 2NRRALG06 & 371954086091000 & $8 / 16 / 2016$ & 1500 & Tetrastrum spp. & Chlorophyta & 4 & 342,233 & $38,705,629$ \\
\hline 2NRRALG06 & 371954086091000 & $8 / 16 / 2016$ & 1500 & Plagioselmis spp. & Cryptophyta & 3 & 256,675 & $21,771,917$ \\
\hline 2NRRALG06 & 371954086091000 & $8 / 16 / 2016$ & 1500 & Aphanizomenon spp. & Cyanobacteria & 11 & 941,141 & $33,262,650$ \\
\hline 2NRRALG06 & 371954086091000 & $8 / 16 / 2016$ & 1500 & Chroococcus microscopicus & Cyanobacteria & 602 & $51,506,095$ & $13,807,875$ \\
\hline 2NRRALG06 & 371954086091000 & $8 / 16 / 2016$ & 1500 & Chroococcus minimus & Cyanobacteria & 24 & $2,053,399$ & $8,601,251$ \\
\hline 2NRRALG06 & 371954086091000 & $8 / 16 / 2016$ & 1500 & cf. Cylindrospermopsis spp. & Cyanobacteria & 1,201 & $102,755,516$ & $645,631,401$ \\
\hline 2NRRALG06 & 371954086091000 & $8 / 16 / 2016$ & 1500 & Dolichospermum spp. & Cyanobacteria & 26 & 10,400 & $1,176,223$ \\
\hline 2NRRALG06 & 371954086091000 & $8 / 16 / 2016$ & 1500 & Merismopedia spp. & Cyanobacteria & 32 & 232,442 & 232,442 \\
\hline 2NRRALG06 & 371954086091000 & $8 / 16 / 2016$ & 1500 & Microcystis spp. & Cyanobacteria & 14 & $1,197,816$ & $78,396,819$ \\
\hline 2NRRALG06 & 371954086091000 & $8 / 16 / 2016$ & 1500 & cf. Planktolyngbya spp. & Cyanobacteria & 97 & $8,299,155$ & $13,036,271$ \\
\hline 2NRRALG06 & 371954086091000 & $8 / 16 / 2016$ & 1500 & Euglena spp. & Euglenophyta & 1 & 400 & 771,896 \\
\hline 2NRRALG06 & 371954086091000 & $8 / 16 / 2016$ & 1500 & Trachelomonas volvocina & Euglenophyta & 1 & 7,264 & $1,901,657$ \\
\hline 2NRRALG06 & 371954086091000 & $8 / 16 / 2016$ & 1500 & cf. Gymnodinium spp. & Pyrrophyta & 2 & 171,117 & $130,452,306$ \\
\hline 2NRRALG06 & 371954086091000 & $8 / 16 / 2016$ & 1500 & Peridinium spp. & Pyrrophyta & 1 & 7,264 & $61,214,337$ \\
\hline
\end{tabular}


Table 6. Cyanobacterial abundance in discrete water-quality samples collected at Nolin River Lake, August 15-19, 2016. - Continued

[USACE, U.S. Army Corps of Engineers; USGS, U.S. Geological Survey; cells/L, cells per liter; $\mu \mathrm{m}^{3} / \mathrm{mL}$, micrometers cubed per milliliter; spp., species; cf, compared with]

\begin{tabular}{|c|c|c|c|c|c|c|c|c|}
\hline $\begin{array}{c}\text { USACE site } \\
\text { number }\end{array}$ & USGS site number & Sample date & Sample time & Genus & Division & Tally & $\begin{array}{l}\text { Density } \\
\text { (cells/L) }\end{array}$ & $\begin{array}{c}\text { Total biovolume } \\
\left(\mu^{3} / \mathrm{L}\right)\end{array}$ \\
\hline 2NRR20003 & 371927086131300 & $8 / 17 / 2016$ & 1600 & Aulacoseira spp. & Bacillariophyta & 4 & 1,600 & 534,076 \\
\hline 2NRR20003 & 371927086131300 & $8 / 17 / 2016$ & 1600 & Cyclotella spp. & Bacillariophyta & 6 & 513,350 & $58,058,444$ \\
\hline 2NRR20003 & 371927086131300 & $8 / 17 / 2016$ & 1600 & Fragilaria tenera & Bacillariophyta & 2 & 171,117 & $43,543,833$ \\
\hline 2NRR20003 & 371927086131300 & $8 / 17 / 2016$ & 1600 & Nitzschia spp. & Bacillariophyta & 1 & 85,558 & $6,160,197$ \\
\hline 2NRR20003 & 371927086131300 & $8 / 17 / 2016$ & 1600 & Closteriopsis acicularis & Chlorophyta & 1 & 400 & 70,686 \\
\hline 2NRR20003 & 371927086131300 & $8 / 17 / 2016$ & 1600 & Coelastrum spp. & Chlorophyta & 8 & 58,110 & 821,516 \\
\hline 2NRR20003 & 371927086131300 & $8 / 17 / 2016$ & 1600 & Cosmarium spp. & Chlorophyta & 2 & 14,528 & $8,671,556$ \\
\hline 2NRR20003 & 371927086131300 & $8 / 17 / 2016$ & 1600 & Drepanochloris nannoselene & Chlorophyta & 7 & 598,908 & $2,032,046$ \\
\hline 2NRR20003 & 371927086131300 & $8 / 17 / 2016$ & 1600 & cf. Eudorina spp. & Chlorophyta & 9 & 65,374 & $17,525,670$ \\
\hline 2NRR20003 & 371927086131300 & $8 / 17 / 2016$ & 1600 & Staurastrum spp. & Chlorophyta & 1 & 400 & 41,888 \\
\hline 2NRR20003 & 371927086131300 & $8 / 17 / 2016$ & 1600 & Tetraedron minimum & Chlorophyta & 6 & 43,583 & $4,706,943$ \\
\hline 2NRR20003 & 371927086131300 & $8 / 17 / 2016$ & 1600 & Tetrastrum spp. & Chlorophyta & 4 & 1,600 & 76,341 \\
\hline 2NRR20003 & 371927086131300 & $8 / 17 / 2016$ & 1600 & Mallomonas spp. & Chrysophyta & 3 & 21,791 & $6,572,126$ \\
\hline 2NRR20003 & 371927086131300 & $8 / 17 / 2016$ & 1600 & Plagioselmis spp. & Cryptophyta & 2 & 171,117 & $31,537,920$ \\
\hline 2NRR20003 & 371927086131300 & $8 / 17 / 2016$ & 1600 & Aphanizomenon spp. & Cyanobacteria & 15 & $1,283,374$ & $31,498,722$ \\
\hline 2NRR20003 & 371927086131300 & $8 / 17 / 2016$ & 1600 & cf. Aphanocapsa spp. & Cyanobacteria & 103 & $8,812,505$ & $4,614,213$ \\
\hline 2NRR20003 & 371927086131300 & $8 / 17 / 2016$ & 1600 & Chroococcus microscopicus & Cyanobacteria & 594 & $50,821,629$ & $13,624,382$ \\
\hline 2NRR20003 & 371927086131300 & $8 / 17 / 2016$ & 1600 & Chroococcus minimus & Cyanobacteria & 24 & $2,053,399$ & $8,601,251$ \\
\hline 2NRR20003 & 371927086131300 & $8 / 17 / 2016$ & 1600 & cf. Cylindrospermopsis spp. & Cyanobacteria & 929 & $79,483,659$ & $499,410,135$ \\
\hline 2NRR20003 & 371927086131300 & $8 / 17 / 2016$ & 1600 & Dolichospermum cf. planctonicum & Cyanobacteria & 28 & 203,386 & $30,669,923$ \\
\hline
\end{tabular}


Table 6. Cyanobacterial abundance in discrete water-quality samples collected at Nolin River Lake, August 15-19, 2016.-Continued

[USACE, U.S. Army Corps of Engineers; USGS, U.S. Geological Survey; cells/L, cells per liter; $\mu \mathrm{m}^{3} / \mathrm{mL}$, micrometers cubed per milliliter; spp., species; cf, compared with]

\begin{tabular}{|c|c|c|c|c|c|c|c|c|}
\hline $\begin{array}{l}\text { USACE site } \\
\text { number }\end{array}$ & USGS site number & Sample date & Sample time & Genus & Division & Tally & $\begin{array}{l}\text { Density } \\
\text { (cells/L) }\end{array}$ & $\begin{array}{c}\text { Total biovolume } \\
\left(\mu \mathrm{m}^{3} / \mathrm{L}\right)\end{array}$ \\
\hline 2NRR20003 & 371927086131300 & $8 / 17 / 2016$ & 1600 & Phacus spp. & Euglenophyta & 1 & 400 & 784,149 \\
\hline 2NRR20003 & 371927086131300 & $8 / 17 / 2016$ & 1600 & Trachelomonas spp. & Euglenophyta & 1 & 400 & 179,701 \\
\hline 2NRR20003 & 371927086131300 & $8 / 17 / 2016$ & 1600 & Peridinium spp. & Pyrrophyta & 3 & 21,791 & $29,483,289$ \\
\hline 2NRRALG05 & 371852086141300 & $8 / 17 / 2016$ & 1300 & Achnanthidium catenatum & Bacillariophyta & 13 & 926,882 & $78,620,810$ \\
\hline 2NRRALG05 & 371852086141300 & $8 / 17 / 2016$ & 1300 & cf. Brachysira vitrea & Bacillariophyta & 25 & $1,782,465$ & $293,988,070$ \\
\hline 2NRRALG05 & 371852086141300 & $8 / 17 / 2016$ & 1300 & Cyclotella spp. & Bacillariophyta & 12 & 855,583 & $72,573,055$ \\
\hline 2NRRALG05 & 371852086141300 & $8 / 17 / 2016$ & 1300 & Fragilaria tenera & Bacillariophyta & 3 & 213,896 & $42,334,282$ \\
\hline 2NRRALG05 & 371852086141300 & $8 / 17 / 2016$ & 1300 & Nitzschia spp. & Bacillariophyta & 2 & 142,597 & $7,272,455$ \\
\hline 2NRRALG05 & 371852086141300 & $8 / 17 / 2016$ & 1300 & Planothidium spp. & Bacillariophyta & 1 & 7,264 & $1,437,653$ \\
\hline 2NRRALG05 & 371852086141300 & $8 / 17 / 2016$ & 1300 & Chlamydomonas globosa & Chlorophyta & 12 & 855,583 & $80,636,728$ \\
\hline 2NRRALG05 & 371852086141300 & $8 / 17 / 2016$ & 1300 & Chlorella spp. & Chlorophyta & 33 & $2,352,853$ & $9,855,600$ \\
\hline 2NRRALG05 & 371852086141300 & $8 / 17 / 2016$ & 1300 & Scenedesmus spp. & Chlorophyta & 14 & 998,180 & $37,630,473$ \\
\hline 2NRRALG05 & 371852086141300 & $8 / 17 / 2016$ & 1300 & cf. Sphaerocystis spp. & Chlorophyta & 16 & 116,221 & $13,144,253$ \\
\hline 2NRRALG05 & 371852086141300 & $8 / 17 / 2016$ & 1300 & Tetraedron minimum & Chlorophyta & 2 & 142,597 & $15,400,494$ \\
\hline 2NRRALG05 & 371852086141300 & $8 / 17 / 2016$ & 1300 & Tetrastrum spp. & Chlorophyta & 4 & 1,600 & 180,957 \\
\hline 2NRRALG05 & 371852086141300 & $8 / 17 / 2016$ & 1300 & Plagioselmis spp. & Cryptophyta & 2 & 142,597 & $26,281,600$ \\
\hline 2NRRALG05 & 371852086141300 & $8 / 17 / 2016$ & 1300 & Chroococcus microscopicus & Cyanobacteria & 400 & $28,519,433$ & $7,645,556$ \\
\hline 2NRRALG05 & 371852086141300 & $8 / 17 / 2016$ & 1300 & Chroococcus minimus & Cyanobacteria & 8 & 570,389 & $2,389,236$ \\
\hline 2NRRALG05 & 371852086141300 & $8 / 17 / 2016$ & 1300 & cf. Cylindrospermopsis spp. & Cyanobacteria & 973 & $69,373,520$ & $435,886,313$ \\
\hline 2NRRALG05 & 371852086141300 & $8 / 17 / 2016$ & 1300 & cf. Planktolyngbya spp. & Cyanobacteria & 121 & $8,627,128$ & $13,551,450$ \\
\hline 2NRRALG05 & 371852086141300 & $8 / 17 / 2016$ & 1300 & Trachelomonas spp. & Euglenophyta & 2 & 14,528 & $12,672,642$ \\
\hline 2NRRALG05 & 371852086141300 & $8 / 17 / 2016$ & 1300 & Peridinium spp. & Pyrrophyta & 1 & 400 & 527,792 \\
\hline 2NRR20001 & 03310900 & $8 / 18 / 2016$ & 1200 & Achnanthidium minutissimum & Bacillariophyta & 27 & 196,123 & $6,777,505$ \\
\hline 2NRR20001 & 03310900 & $8 / 18 / 2016$ & 1200 & Brachysira spp. & Bacillariophyta & 10 & 855,583 & $210,663,452$ \\
\hline 2NRR20001 & 03310900 & $8 / 18 / 2016$ & 1200 & Cyclotella spp. & Bacillariophyta & 5 & 427,791 & $48,382,037$ \\
\hline 2NRR20001 & 03310900 & $8 / 18 / 2016$ & 1200 & Fragilaria tenera & Bacillariophyta & 3 & 256,675 & $41,931,099$ \\
\hline 2NRR20001 & 03310900 & $8 / 18 / 2016$ & 1200 & Chlamydomonas spp. & Chlorophyta & 8 & 684,466 & $35,838,546$ \\
\hline 2NRR20001 & 03310900 & 8/18/2016 & 1200 & Chlorella spp. & Chlorophyta & 63 & $5,390,173$ & $76,201,708$ \\
\hline 2NRR20001 & 03310900 & $8 / 18 / 2016$ & 1200 & Coelastrum spp. & Chlorophyta & 12 & 87,166 & $2,920,945$ \\
\hline
\end{tabular}


Table 6. Cyanobacterial abundance in discrete water-quality samples collected at Nolin River Lake, August 15-19, 2016. - Continued

[USACE, U.S. Army Corps of Engineers; USGS, U.S. Geological Survey; cells/L, cells per liter; $\mu \mathrm{m}^{3} / \mathrm{mL}$, micrometers cubed per milliliter; spp., species; cf, compared with]

\begin{tabular}{|c|c|c|c|c|c|c|c|c|}
\hline $\begin{array}{l}\text { USACE site } \\
\text { number }\end{array}$ & USGS site number & Sample date & Sample time & Genus & Division & Tally & $\begin{array}{l}\text { Density } \\
\text { (cells/L) }\end{array}$ & $\begin{array}{c}\text { Total biovolume } \\
\left(\mu \mathrm{m}^{3} / \mathrm{L}\right)\end{array}$ \\
\hline 2NRR20001 & 03310900 & $8 / 18 / 2016$ & 1200 & Cosmarium spp. & Chlorophyta & 1 & 400 & 318,351 \\
\hline 2NRR20001 & 03310900 & $8 / 18 / 2016$ & 1200 & cf. Eudorina spp. & Chlorophyta & 7 & 2,800 & 750,638 \\
\hline 2NRR20001 & 03310900 & $8 / 18 / 2016$ & 1200 & Scenedesmus spp. & Chlorophyta & 12 & $1,026,700$ & $53,220,240$ \\
\hline 2NRR20001 & 03310900 & $8 / 18 / 2016$ & 1200 & Tetraedron minimum & Chlorophyta & 1 & 85,558 & $6,416,872$ \\
\hline 2NRR20001 & 03310900 & $8 / 18 / 2016$ & 1200 & Plagioselmis nannoplanctica & Cryptophyta & 6 & 513,350 & $43,543,833$ \\
\hline 2NRR20001 & 03310900 & $8 / 18 / 2016$ & 1200 & Aphanizomenon spp. & Cyanobacteria & 30 & 217,914 & $2,738,386$ \\
\hline 2NRR20001 & 03310900 & $8 / 18 / 2016$ & 1200 & Chroococcus microscopicus & Cyanobacteria & 346 & $29,603,171$ & $7,936,088$ \\
\hline 2NRR20001 & 03310900 & $8 / 18 / 2016$ & 1200 & cf. Cylindrospermopsis spp. & Cyanobacteria & 2315 & $198,067,460$ & $1,244,493,501$ \\
\hline 2NRR20001 & 03310900 & $8 / 18 / 2016$ & 1200 & cf. Microcystis spp. & Cyanobacteria & 11 & 941,141 & $21,127,943$ \\
\hline 2NRR20001 & 03310900 & $8 / 18 / 2016$ & 1200 & Microcystis spp. & Cyanobacteria & 44 & 319,607 & $15,249,387$ \\
\hline 2NRR20001 & 03310900 & $8 / 18 / 2016$ & 1200 & cf. Planktolyngbya spp. & Cyanobacteria & 129 & $11,037,020$ & $17,336,896$ \\
\hline 2NRR20001 & 03310900 & $8 / 18 / 2016$ & 1200 & Planktothrix spp. & Cyanobacteria & 25 & 10,000 & 212,059 \\
\hline 2NRR20001 & 03310900 & $8 / 18 / 2016$ & 1200 & Peridinium spp. & Pyrrophyta & 2 & 800 & $2,303,856$ \\
\hline 2NRR20034 & 372105086061500 & $8 / 19 / 2016$ & 0930 & Achnanthidium catenatum & Bacillariophyta & 5 & 427,791 & $26,206,937$ \\
\hline 2NRR20034 & 372105086061500 & $8 / 19 / 2016$ & 0930 & cf. Brachysira vitrea & Bacillariophyta & 1 & 85,558 & $12,901,876$ \\
\hline 2NRR20034 & 372105086061500 & $8 / 19 / 2016$ & 0930 & Cyclotella spp. & Bacillariophyta & 54 & $4,620,148$ & $272,148,957$ \\
\hline 2NRR20034 & 372105086061500 & $8 / 19 / 2016$ & 0930 & Fragilaria tenera & Bacillariophyta & 3 & 256,675 & $49,994,771$ \\
\hline 2NRR20034 & 372105086061500 & $8 / 19 / 2016$ & 0930 & Navicula spp. & Bacillariophyta & 1 & 400 & 124,408 \\
\hline 2NRR20034 & 372105086061500 & $8 / 19 / 2016$ & 0930 & Nitzschia acicularis & Bacillariophyta & 1 & 85,558 & $9,496,971$ \\
\hline 2NRR20034 & 372105086061500 & $8 / 19 / 2016$ & 0930 & Nitzschia fruticosa & Bacillariophyta & 2 & 14,528 & 828,073 \\
\hline 2NRR20034 & 372105086061500 & $8 / 19 / 2016$ & 0930 & Nitzschia spp. & Bacillariophyta & 6 & 513,350 & $29,260,938$ \\
\hline 2NRR20034 & 372105086061500 & $8 / 19 / 2016$ & 0930 & Chlamydomonas spp. & Chlorophyta & 5 & 427,791 & $22,399,091$ \\
\hline 2NRR20034 & 372105086061500 & $8 / 19 / 2016$ & 0930 & Chlorella spp. & Chlorophyta & 62 & $5,304,614$ & $22,219,898$ \\
\hline 2NRR20034 & 372105086061500 & $8 / 19 / 2016$ & 0930 & cf. Oocystis spp. & Chlorophyta & 4 & 29,055 & $1,947,297$ \\
\hline 2NRR20034 & 372105086061500 & $8 / 19 / 2016$ & 0930 & cf. Pediastrum spp. & Chlorophyta & 8 & 3,200 & 272,379 \\
\hline 2NRR20034 & 372105086061500 & $8 / 19 / 2016$ & 0930 & Scenedesmus spp. & Chlorophyta & 12 & $1,026,700$ & $38,705,629$ \\
\hline 2NRR20034 & 372105086061500 & $8 / 19 / 2016$ & 0930 & Tetraedron minimum & Chlorophyta & 2 & 14,528 & $1,568,981$ \\
\hline 2NRR20034 & 372105086061500 & $8 / 19 / 2016$ & 0930 & Plagioselmis spp. & Cryptophyta & 7 & 598,908 & $50,801,139$ \\
\hline 2NRR20034 & 372105086061500 & $8 / 19 / 2016$ & 0930 & Anabaenopsis circularis & Cyanobacteria & 12 & 4,800 & 301,596 \\
\hline
\end{tabular}


Table 6. Cyanobacterial abundance in discrete water-quality samples collected at Nolin River Lake, August 15-19, 2016.-Continued

[USACE, U.S. Army Corps of Engineers; USGS, U.S. Geological Survey; cells/L, cells per liter; $\mu \mathrm{m}^{3} / \mathrm{mL}$, micrometers cubed per milliliter; spp., species; cf, compared with]

\begin{tabular}{|c|c|c|c|c|c|c|c|c|}
\hline $\begin{array}{l}\text { USACE site } \\
\text { number }\end{array}$ & USGS site number & Sample date & Sample time & Genus & Division & Tally & $\begin{array}{l}\text { Density } \\
\text { (cells/L) }\end{array}$ & $\begin{array}{c}\text { Total biovolume } \\
\left(\mu \mathrm{m}^{3} / \mathrm{L}\right)\end{array}$ \\
\hline 2NRR20034 & 372105086061500 & $8 / 19 / 2016$ & 0930 & Aphanocapsa spp. & Cyanobacteria & 102 & $8,726,946$ & $4,569,415$ \\
\hline 2NRR20034 & 372105086061500 & $8 / 19 / 2016$ & 0930 & Chroococcus microscopicus & Cyanobacteria & 862 & $73,751,253$ & $19,771,409$ \\
\hline 2NRR20034 & 372105086061500 & $8 / 19 / 2016$ & 0930 & Chroococcus minimus & Cyanobacteria & 16 & $1,368,933$ & $5,734,167$ \\
\hline 2NRR20034 & 372105086061500 & $8 / 19 / 2016$ & 0930 & cf. Cylindrospermopsis spp. & Cyanobacteria & 160 & $13,689,328$ & $86,012,510$ \\
\hline 2NRR20034 & 372105086061500 & $8 / 19 / 2016$ & 0930 & Merismopedia spp. & Cyanobacteria & 80 & $6,844,664$ & $6,844,664$ \\
\hline 2NRR20034 & 372105086061500 & $8 / 19 / 2016$ & 0930 & Microcystis spp. & Cyanobacteria & 15 & $1,283,374$ & $83,996,592$ \\
\hline 2NRR20034 & 372105086061500 & $8 / 19 / 2016$ & 0930 & cf. Planktolyngbya spp. & Cyanobacteria & 77 & $6,587,989$ & $10,348,380$ \\
\hline 2NRR20034 & 372105086061500 & $8 / 19 / 2016$ & 0930 & Pseudanabaena spp. & Cyanobacteria & 274 & $23,442,974$ & $294,592,846$ \\
\hline 2NRR20034 & 372105086061500 & $8 / 19 / 2016$ & 0930 & Trachelomonas spp. & Euglenophyta & 1 & 7,264 & $2,472,154$ \\
\hline
\end{tabular}




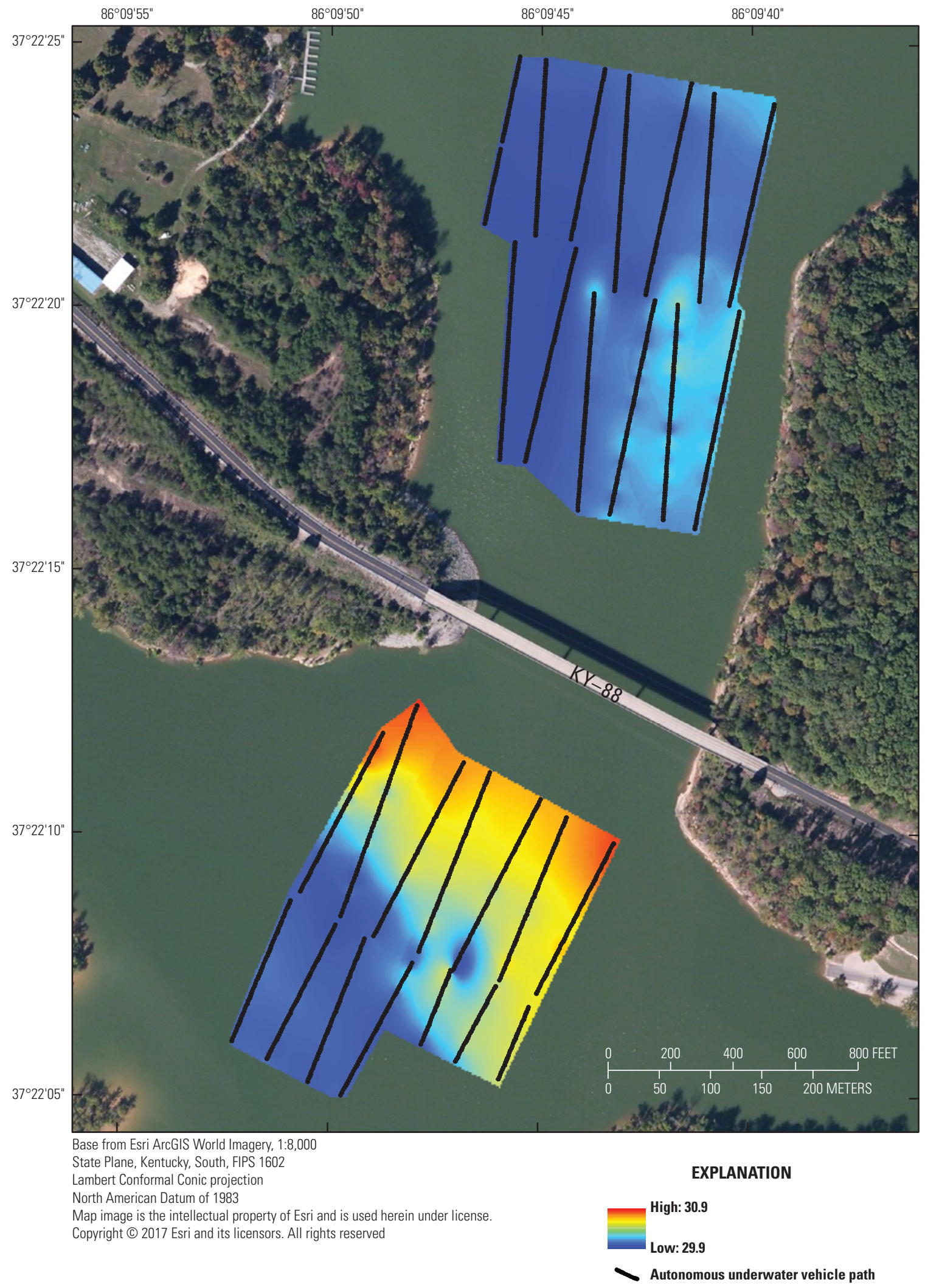

Figure 7. Water temperature at 5 feet below the surface at site 2NRRROCKC, Nolin River Lake, August 15, 2016. 
Results of the data collected on August 16, 2016, at site 2NRRALG06 showed a vertical distribution of decreasing mean water temperature with depth. No data were collected at layer 2 (10 ft below water surface) at site 2NRRALG06 because of weather concerns, boat traffic, and time constraints on that day. The mean water temperature ranged from $30.3^{\circ} \mathrm{C}$ in layer 1 to $28.3^{\circ} \mathrm{C}$ in layer 3 ( 5 and $15 \mathrm{ft}$ below the surface, respectively) (table 4). The distribution of DO values were uniform within each layer, but different between layers with the mean DO value in layers 1 and 3 of 7.9 and $0.5 \mathrm{mg} / \mathrm{L}$, respectively (table 4). Similar to the distribution of DO values, $\mathrm{pH}$ values showed a somewhat uniform distribution in each layer; however, the $\mathrm{pH}$ values also showed a vertical distribution of decreasing values with depth. Layer 1 had a mean $\mathrm{pH}$ value of 8.6 standard units, whereas layer 3 had a mean $\mathrm{pH}$ value of 7.4 standard units (table 4). The distribution of SC values was uniform in layers 1 and 3 with a mean value of $0.208 \mathrm{mS} / \mathrm{cm}$ and $0.229 \mathrm{mS} / \mathrm{cm}$, respectively (table 4). Values of SC in layer 3 showed a distribution of lower to higher values as the water moved toward the main reservoir channel. In general, the distribution of turbidity was consistent to a depth of $15 \mathrm{ft}$, with mean turbidity values of less than $5 \mathrm{FNU}$ in layers 1 and 3 (table 4). The distribution of chlorophyll did not show any specific pattern. Mean values of chlorophyll were 8.7 and $11.5 \mu \mathrm{g} / \mathrm{L}$ in layers 1 and 3, respectively (table 4).

Results of the data collected on August 17, 2016, at site 2NRRALG05 showed the distribution of water temperature to be uniform within each layer. Mean water temperature varied among the selected layers with a $5.4{ }^{\circ} \mathrm{C}$ difference between layers 1 and 4 . Mean values of water temperature among the layers ranged from 29.7 to $24.3^{\circ} \mathrm{C}$, indicating thermal stratification (table 4). Mean values of DO ranged from 0.9 to $8.1 \mathrm{mg} / \mathrm{L}$ (table 4). The distribution of $\mathrm{pH}$ values was uniform within each layer. The mean value of $\mathrm{pH}$ was higher in layer 1 at 8.7 standard units. Layers 2 and 4 showed lower mean $\mathrm{pH}$ values that ranged from 7.6 and 7.5 standard units, respectively (table 4). The distribution of SC among the layers showed increasing values with depth. The mean values of SC ranged from $0.217 \mathrm{mS} / \mathrm{cm}$ in layer 1 to $0.316 \mathrm{mS} / \mathrm{cm}$ in layer 4 (table 4). The distribution of turbidity was consistent to a depth of $25 \mathrm{ft}$, with mean values being less than $5 \mathrm{FNU}$ in all layers (table 4). The distribution of chlorophyll did not show any specific pattern. Mean values of chlorophyll were highest in layer 3 at $11.5 \mu \mathrm{g} / \mathrm{L}$ and lowest in layer 4 at $5.7 \mu \mathrm{g} / \mathrm{L}$ (table 4 ).

Results of the data collected on August 17, 2016, at site 2NRR20003 showed the distribution of water temperature to be uniform within each layer; however, the site had a vertical distribution of decreasing water temperature with depth. The mean water temperature ranged from $29.7^{\circ} \mathrm{C}$ in layer 1 to $24.2^{\circ} \mathrm{C}$ in layer 4 (table 4). The distribution of DO values also was uniform within each layer. Mean values of DO ranged from $0.5 \mathrm{mg} / \mathrm{L}$ in layer 4 to $8.4 \mathrm{mg} / \mathrm{L}$ in layer 1 (table 4 ). Layers 2 and 4 had consistent mean DO values. Mean values of $\mathrm{pH}$ showed a vertical distribution of decreasing $\mathrm{pH}$ with depth. Mean values of $\mathrm{pH}$ ranged from 7.4 standard units in layer 4 to 8.8 standard units with layer 1 (table 4). Unlike other field water-quality parameters, mean SC values showed a vertical distribution of increasing values with depth. Layer 1 had the lowest mean SC value of $0.213 \mathrm{mS} / \mathrm{cm}$ and layer 4 had the highest mean SC value of $0.294 \mathrm{mS} / \mathrm{cm}$ (table 4). The distribution of turbidity values was consistent to a depth of $25 \mathrm{ft}$, with mean values being less than $5 \mathrm{FNU}$ in all layers (table 4). The distribution of estimated chlorophyll showed a consistent pattern with higher values near the shoreline (fig. 8). The mean value of chlorophyll was about 50-percent higher in layers 1 and 2 than in layer 4 (table 4).

Results of the data collected on August 18, 2016, at site 2NRR20001 (lacustrine zone) showed the distribution of water temperature to be uniform within each layer. The site also showed a vertical distribution of decreasing water temperature with depth (table 4). Water temperature ranged from $29.0^{\circ} \mathrm{C}$ in layer 1 to $24.2^{\circ} \mathrm{C}$ in layer 4 (table 4). The distribution of DO showed that values of DO increase from the eastern shoreline to the western shoreline at all measured depths. Values of DO ranged from $0.4 \mathrm{mg} / \mathrm{L}$ in layer 4 to $8.3 \mathrm{mg} / \mathrm{L}$ in layer 1 (table 4). Values of $\mathrm{pH}$ were uniformly distributed in each layer, with mean $\mathrm{pH}$ values that ranged from 7.4 standard units in layer 4 to 8.7 standard units in layer 1 (table 4). Mean $\mathrm{pH}$ values above 8.6 standard units occurred in layers 1 and 2 (table 4). Mean values of SC showed a vertical distribution of increasing values with depth, with values being uniform within each layer. Mean values of SC ranged from $0.230 \mathrm{mS} / \mathrm{cm}$ in layer 1 to $0.279 \mathrm{mS} / \mathrm{cm}$ in layer 4 (table 4). The distribution of turbidity was consistent to a depth of $25 \mathrm{ft}$, with mean turbidity values being less than $5 \mathrm{FNU}$ in layers 1 through 4 (table 4). The distribution of mean chlorophyll was uniform with depth, with values that ranged from 8.5 to $10.9 \mu \mathrm{g} / \mathrm{L}$ (table 4).

Results of the data collected on August 19, 2016, at site 2NRR20034 (riverine zone) showed that in layer 1, water temperature increased from the outer shoreline to the inner shoreline of the U-shaped river bend. The difference in water temperature between the shorelines was $0.9^{\circ} \mathrm{C}$ in layer 1 , $0.6^{\circ} \mathrm{C}$ in layer 2 , and $0.2^{\circ} \mathrm{C}$ in layer 3 (Crain and others, 2019). Similar to the other sites, site 2NRR20034 showed a vertical distribution of decreasing mean water temperature with depth (table 4). The distribution of DO values also was uniform within each layer, but in general decreased with depth. Mean values of DO ranged from $6.0 \mathrm{mg} / \mathrm{L}$ in layer 2 to $9.0 \mathrm{mg} / \mathrm{L}$ at the surface, with all layers having mean DO values greater than $5 \mathrm{mg} / \mathrm{L}$ (table 4). Values of $\mathrm{pH}$ showed a somewhat uniform distribution in each layer; however, the values also showed a vertical distribution of decreasing mean values with depth. Mean values of $\mathrm{pH}$ for the surface and layer 1 exhibited alkaline $\mathrm{pH}$ values, with mean $\mathrm{pH}$ values of 8.9 and 8.5 standard units, respectively. Layers 2 and 3 showed more neutral mean $\mathrm{pH}$ values (table 4). Values of SC showed a vertical distribution of increasing mean values with depth, with values being uniform within each layer. Mean values of SC ranged from $0.191 \mathrm{mS} / \mathrm{cm}$ at the surface to $0.356 \mathrm{mS} / \mathrm{cm}$ at layer 3 (table 4 ). The distribution of turbidity showed increasing mean values with depth (table 4). The range of mean turbidity values including all layers was from 


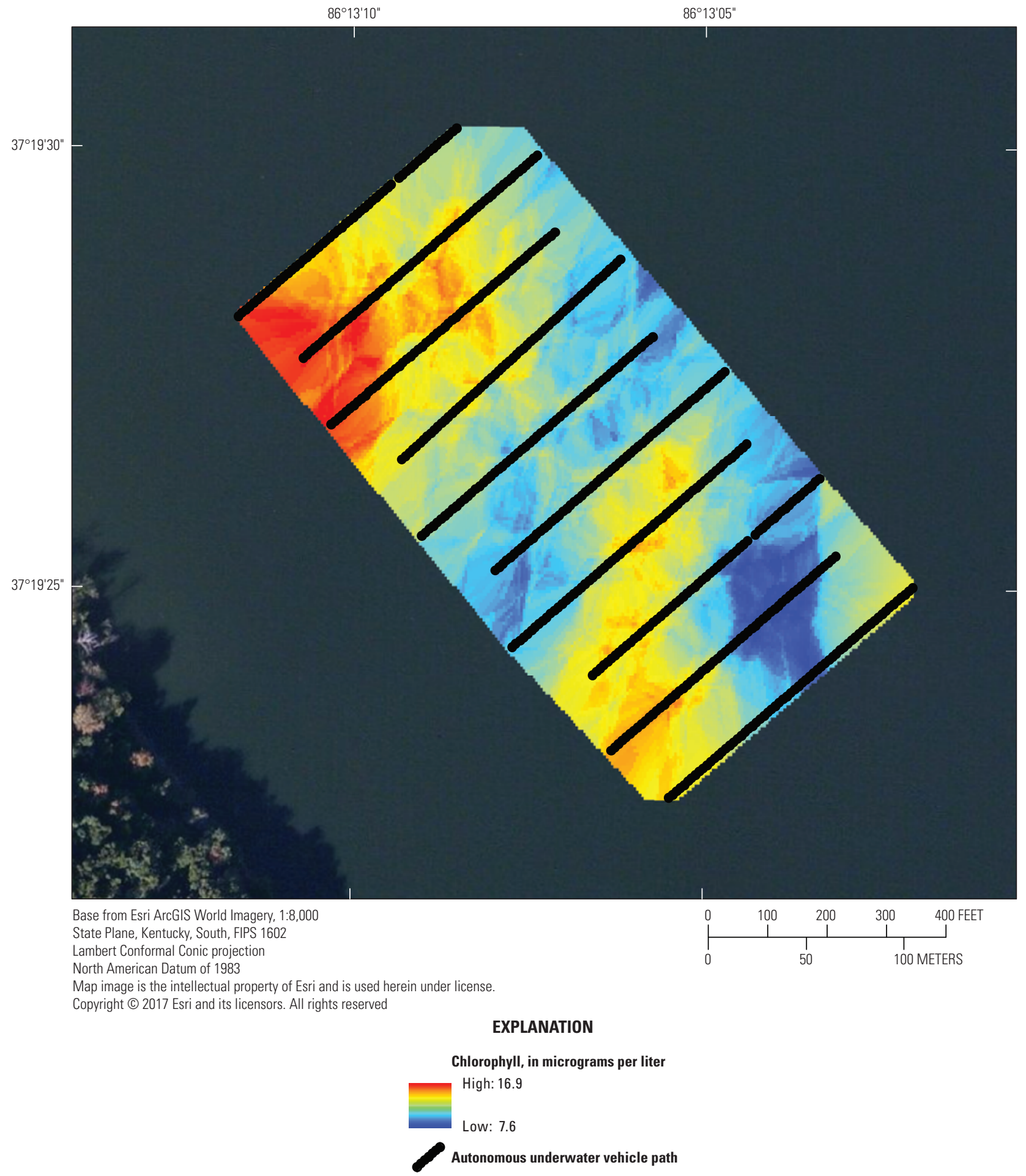

Figure 8. Chlorophyll values at 15 feet below the surface at site 2NRR20003, Nolin River Lake, August 17, 2016. 


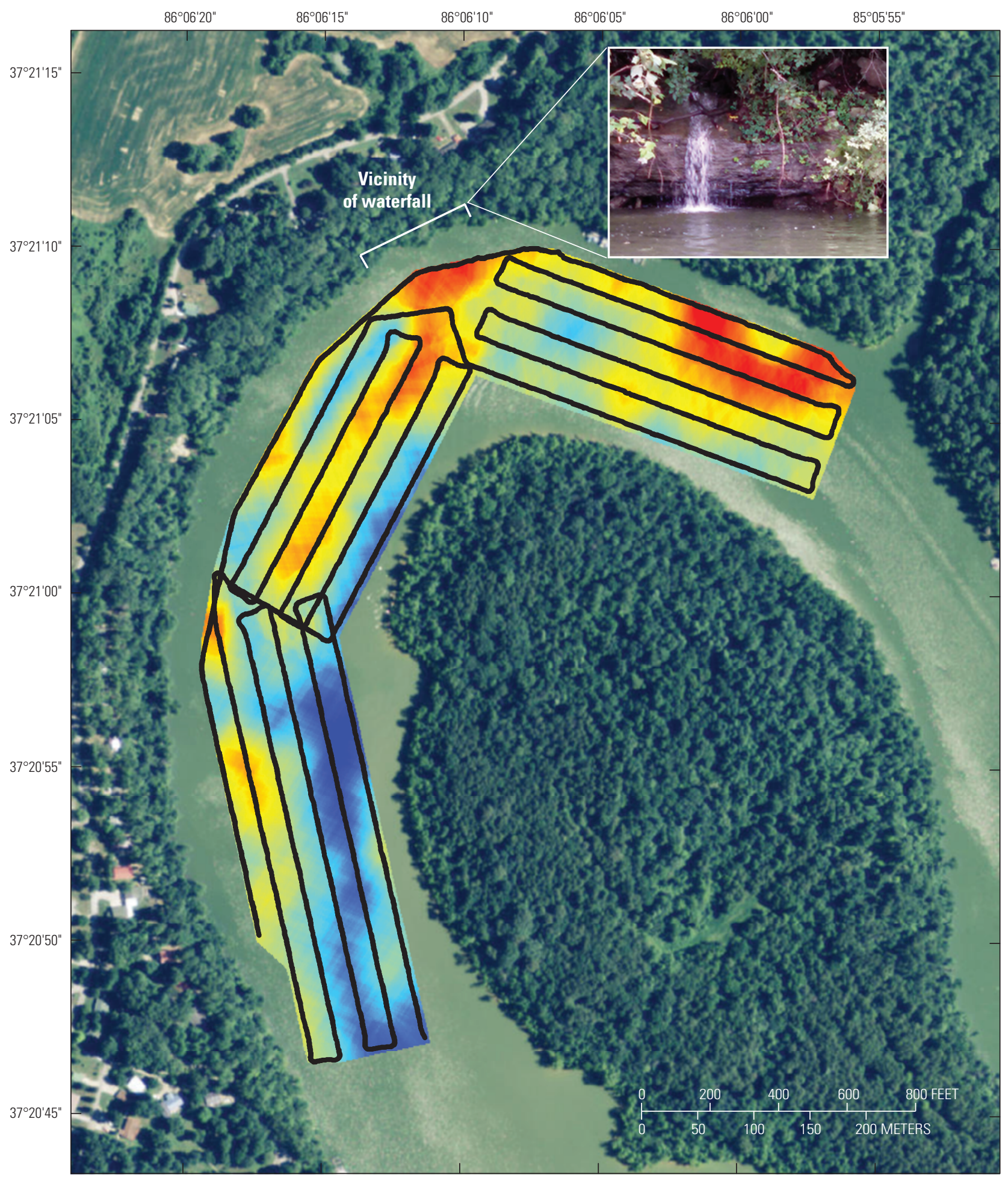

Base from Esri ArcGIS World Imagery, 1:8,000 State Plane, Kentucky, South, FIPS 1602

Lambert Conformal Conic projection

North American Datum of 1983

Map image is the intellectual property of Esri and is used herein under license.

Copyright (C) 2009 Esri and its licensors. All rights reserved

\section{EXPLANATION}

Chlorophyll, in micrograms per liter

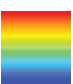

High: 23.4

Low: 8.4

Autonomous underwater vehicle path

Figure 9. Chlorophyll values in the surface layer at site 2NRR20034, Nolin River, August 19, 2016. 
7.2 to 31 FNU. Mean turbidity values in layers 2 and 3 were about 3- to 4-times higher than in layer 1 (table 4). Mean chlorophyll values were highest near the water surface $(16.0 \mu \mathrm{g} / \mathrm{L})$ (table 4), with the highest chlorophyll values measured near a tributary flowing into the lake and a waterfall downstream of the tributary near the outside bend of the river (fig. 9).

\section{Water-Quality Data in Discrete Samples}

Discrete samples were collected at a depth of $3 \mathrm{ft}$ below the surface and concentrations of nutrients, chlorophyll $a$, and pheophytin $a$ were determined for all sites in Nolin River Lake. Concentrations of total nitrogen as nitrogen ranged from $0.723 \mathrm{mg} / \mathrm{L}$ at site 2NRRALG05 to $4.84 \mathrm{mg} / \mathrm{L}$ at site 2NRR20003 (table 5). Nitrate plus nitrite as nitrogen concentrations ranged from less than $0.04 \mathrm{mg} / \mathrm{L}$ at sites 2NRRROCKC, 2NRRALG05, and 2NRR20003 to $0.145 \mathrm{mg} / \mathrm{L}$ at site 2NRR20034 (riverine site) (table 5). Review of the ammonia as nitrogen concentrations revealed likely sample contamination. Other projects throughout the USGS observed a high frequency of detection of ammonia as nitrogen in blanks during the same time period as this study, and a national assessment of ammonia as nitrogen contamination in environmental surface-water samples was completed. Results of the USGS national assessment determined the cause of the detections to be sample processing at the analyzing laboratory. The issue with the ammonia as nitrogen concentrations does not indicate issues with the concentrations of nitrate plus nitrite as nitrogen, total phosphorus as phosphorus, or orthophosphate as phosphorus.

Total phosphorus as phosphorus concentrations ranged from $0.02 \mathrm{mg} / \mathrm{L}$ at sites 2NRRALG05 and 2NRR20001 to $0.07 \mathrm{mg} / \mathrm{L}$ at site 2NRR20034 (table 5). Concentrations of orthophosphate as phosphorus were below the method detection limit of $0.004 \mathrm{mg} / \mathrm{L}$ at all sampling sites in Nolin River Lake (table 5).

Chlorophyll is commonly used as an estimate of algal biomass (Hambrook Berkman and Canova, 2007). Concentrations of chlorophyll $a$ in Nolin River Lake ranged from $8.45 \mu \mathrm{g} / \mathrm{L}$ at site $2 \mathrm{NRRROCKC}$ on August 15, 2016, to $36.1 \mu \mathrm{g} / \mathrm{L}$ at site 2NRR20034 on August 19, 2016 (table 5). A similar pattern was observed with concentrations of pheophytin $a$, with values that ranged from $2.14 \mu \mathrm{g} / \mathrm{L}$ at site 2NRRROCKC to $10.2 \mu \mathrm{g} / \mathrm{L}$ at site 2NRR20034 (table 5).

The phytoplankton community in Nolin River Lake the week of August 15-19, 2016, was almost exclusively (greater than 90 percent of total phytoplankton abundance) cyanobacteria (division Cyanobacteria). The cyanobacterial community was dominated at five of the six sampling sites by a species of Cylindrospermopsis. The exception was site 2NRR20034, which had a cyanobacterial community dominated by Chroococcus microscopicus. Cyanobacterial abundance ranged from 4,800 cells per liter (cells/L) at site 2NRR20034 (riverine site) to $198,067,460$ cells/L at site 2NRR20001 (dam) (table 6). During the August survey, the second and third most abundant algal divisions were Chlorophyta (green algae) and Bacillariophyta (diatoms), respectively. The abundances of these divisions varied among the sites (table 6). Several potential toxin-producing cyanobacteria genera were identified in Nolin Lake during the August survey; the most abundant was Cylindrospermopsis with abundances ranging from 13,689,328 cells/L at site 2NRR20034 to $198,067,460$ cells/L at site 2NRR20001 (table 6). Although federal regulations or guidelines do not exist for cyanobacteria abundance in recreational water in the United States, the World Health Organization does provide guidance levels. The World Health Organization guidance levels for moderate and high relative probability of acute health effects during recreational exposure to cyanobacteria are $20,000,000$ cells/L to $100,000,000$ cells/L for moderate level acute health effects and 100,000,000 cells/L to $10,000,000,000$ cells/L for high level acute health effects (Chorus and Bartram, 1999).

\section{Limitations}

The hydrogeological information did not include spatial distribution or hydraulic properties for unconsolidated deposits that blanket the bottom of the reservoir or the faults that intersect the lake. That information might improve understanding of the potential for interaction of groundwater and surface water. Additionally, groundwater hydraulic gradients that would indicate the general directions of flow near the reservoir, were not measured during this study or, in particular, during the water-quality measurements.

The AUV surveys were not precisely where karst features and faults might exist beneath the water line. Future survey sites should be determined by utilizing all available information and augmenting with new information where possible. Presurvey information should be collected before attempting additional surveys that are near to the reservoir bottom or the shoreline to ensure the AUV would not become irretrievably lodged in debris. Surveys nearer to the reservoir bottom are more likely to identify spatial anomalies in water-quality parameters that potentially represent groundwater discharges.

The discrete water-quality samples were collected from August 15 to 19, 2016. Water quality in the reservoir might show different patterns during different hydrologic conditions and seasons. Sampling from greater depths, particularly nearer to the bottom of the reservoir, might potentially reveal contrasts indicative of groundwater flow into the reservoir.

Quality-assurance data were not collected during discrete-sample collection or EcoMapper measurements. Qualityassurance data are used to document measurement accuracy, repeatability, and variability of measurements. 


\section{Summary}

A synoptic study of water quality at Nolin River Lake was conducted by the U.S. Geological Survey in collaboration with the U.S. Army Corps of Engineers, Louisville District during August 2016. The purpose of the study was to develop a better understanding of the potential for interaction between groundwater and surface water at Nolin River Lake, Kentucky. This study (1) compiled and interpreted existing information to characterize the hydrogeological setting and implications for potential interaction of groundwater and surface water in the Nolin River Lake watershed; (2) collected transects of onsite water-quality parameters using an autonomous underwater vehicle (AUV) in areas where groundwater discharges to the reservoir were suspected, including five sites on Nolin River Lake and one site on the Nolin River; and (3) collected discrete water-quality and phytoplankton community data at the same six sites.

The preliminary findings from a hydrogeological characterization, AUV reconnaissance surveys, and discrete waterquality sampling of Nolin River Lake are consistent. The available hydrogeological information and water-quality data did not find evidence to indicate that groundwater is discharging to the reservoir by preferential flow through karst features; however, permeable bedrock at the shoreline and beneath the reservoir have the capability to discharge groundwater by intergranular flow. More information is needed to refine the understanding provided in this report. Conclusions drawn from separate elements of this study are enumerated below:

1. A hydrogeological characterization of the Nolin River Lake watershed indicated that groundwater interaction with the reservoir is likely occurring as intergranular flow through bedrock beneath and immediately adjacent to the reservoir and perhaps as preferential flow where faults intercept the reservoir. Groundwater discharges from karst features into the Nolin River upstream from the reservoir but few karst features were mapped beneath or immediately adjacent to the reservoir.

2. The August AUV surveys did not identify localized anomalies in measurements of water-quality parameters that indicate a zone of groundwater discharging from karst or fault-related features. Spatial distributions of water-quality parameters were generally uniform within each constant-depth layer selected above, within, and below the thermocline and ranged from the water surface to 25 feet.

3. The concentrations of nitrate plus nitrite as nitrogen, total phosphorus as phosphorus, chlorophyll $a$, and pheophytin $a$ in discrete water-quality samples from the Nolin River Lake riverine site were higher than in samples from the Nolin River Lake sites during August 2016. Concentrations of most nutrients and chlorophyll $a$ at all sampling sites did exceed the 25 th percentile of median concentrations of nitrate plus nitrite ( 0.101 milligram per liter $[\mathrm{mg} / \mathrm{L}], 0.005 \mathrm{mg} / \mathrm{L})$, total phosphorus $(0.02 \mathrm{mg} / \mathrm{L}$, $0.03 \mathrm{mg} / \mathrm{L}$ ) and chlorophyll $a$ (6.25 micrograms per liter, 12.9 micrograms per liter) as measured by EPA at other lakes and reservoirs in EPA level IV ecoregions 71a and $72 \mathrm{~h}$, respectively. The exception was the concentrations of total phosphorus as phosphorus at the reservoir sites that did not exceed the 25th percentile of median concentrations measured by EPA $(0.03 \mathrm{mg} / \mathrm{L})$ in ecoregion $72 \mathrm{~h}$. The phytoplankton community in Nolin River Lake was almost exclusively (greater than 90 percent of total phytoplankton abundance) cyanobacteria. The prominent cyanobacterial species at the riverine site (Chroococcus microscopicus) differed from the most abundant cyanobacterial species at the five reservoir sites (a species of Cylindrospermopsis).

4. Managing water and biological quality at Nolin RiverLake might benefit from a thorough understanding of the water budget, mapping the unconsolidated sediment distribution and bedrock on the reservoir bottom, measuring the hydraulic properties of the deposits that form the bottom of the reservoir, studying the hydraulic properties of faults near the reservoir, and analyzing water quality nearer to the bottom of the reservoir at sites where karst or faults are precisely located.

\section{References Cited}

Arar, E.J., and Collins, G.B., 1997, Method 445.0 in vitro determination of chlorophyll $a$ and pheophytin $a$ in marine and freshwater algae by fluorescence, revision 1.2: Cincinnati, Ohio, U.S. Environmental Protection Agency, National Exposure Research Laboratory, Office of Research and Development, 22 p., accessed December 12, 2018, at https://cfpub.epa.gov/si/si_public_record_report. cfm?Lab=NERL\&dirEntryId=309417.

Carey, D.I., and Hounshell, T.D., 2008, Kentucky terrain: Kentucky Geological Survey, Map and Chart 187, Series XII, 1 sheet, accessed December 12, 2018, at https://kgs. uky.edu/kgsweb/download/mc187_12.pdf.

Chorus, I., and Bartram, J., eds., 1999, Toxic cyanobacteria in water-A guide to their public health consequences, monitoring and management: Boca Raton, Fla., CRC Press, $416 \mathrm{p}$.

Climate-Data.org, 2018, Climate-Kentucky: Climate-Data. org web page, accessed December 10, 2018, at https:// en.climate-data.org/north-america/united-states-of-america/ kentucky-988/. 
Crain, A.S., Boldt, J.A., Young, J.L., Thomason, J.C., Wolf, Z.L., Bayless, E.R., and Bunch, A.R., 2019, Water-quality datasets from synoptic surveys in Nolin River Lake, Kentucky, using an autonomous underwater vehicle, discrete sampling, and depth profiles, August 2016: U.S. Geological Survey data release, https://doi.org/10.5066/F798857D.

Fishman, M.J., ed., 1993, Methods of analysis by the U.S. Geological Survey National Water Quality LaboratoryDetermination of inorganic and organic constituents in water and fluvial sediments, U.S. Geological Survey OpenFile Report 93-125, 217 p. [Also available at https://doi. org/10.3133/ofr93125.]

George, A.I., 1989, Caves and drainage north of the Green River, in White, W.B., and White, E.L., eds., Karst hydrology: Boston, Mass., Springer, p. 189-221. [Also available at https://doi.org/10.1007/978-1-4615-7317-3_8.]

Gildersleeve, B., 1971, Geologic map of the Nolin Reservoir quadrangle, western Kentucky: U.S. Geological Survey, Geologic Quadrangle Map GQ-895, scale 1:24,000, accessed December 12, 2018, at https://ngmdb.usgs.gov/ ngm-bin/pdp/zui_viewer.pl?id=27662.

Hambrook Berkman, J.A., and Canova, M.G., 2007, Algal biomass indicators (ver. 1.0): U.S. Geological Survey Techniques of Water-Resources Investigations, book 9, chap. A7, sec. 7.4. [Also available at https://water.usgs.gov/owq/ FieldManual/Chapter7/7.4.pdf.]

Hillebrand, H., Dürselen, C.D., Kirschtel, D., Pollingher, U., and Zohary, T., 1999, Biovolume calculation for pelagic and benthic microalgae: Journal of Phycology, v. 35, no. 2, p. 403-424. [Also available at https://doi.org/10.1046/ j.1529-8817.1999.3520403.x.]

Jackson, P.R., 2013, Circulation, mixing, and transport in nearshore Lake Erie in the vicinity of Villa Angela Beach and Euclid Creek, Cleveland, Ohio, September 11-12, 2012: U.S. Geological Survey Scientific Investigations Report 2013-5198, 34 p. [Also available at https://doi.org/10.3133/ sir20135198.]

James, W.F., and Barko, J.W., 1991, Littoral-pelagic phosphorus dynamics during nighttime convective circulation: Limnology and Oceanography, v. 36, no. 5, p. 949-960. [Also available at https://doi.org/10.4319/lo.1991.36.5.0949.]

Kentucky Department for Environmental Protection, 2014, Potentially harmful algal blooms identified in several Kentucky lakes: Frankfort, Ky., Naturally connected-A blog of the Kentucky Energy and Environment Cabinet, accessed August 1, 2018, at https://kydep.wordpress. com/2014/06/19/potentially-harmful-algal-blooms-identified-in-several-kentucky-lakes/.
Kleber, J.E., ed., 1992, Lakes, in Clark, T.E., Harrison, L.H., and Klotter, J.C., eds, The Kentucky Encyclopedia: Lexington, Ky., University Press of Kentucky, 1,080 p.

Lund, J.W.G., Kipling, C., and Le Cren, E.D., 1958, The inverted microscope method of estimating algal numbers and the statistical basis of estimations by counting: Hydrobiologia, v. 11, no. 2, p. 143-170. [Also available at https:// doi.org/10.1007/BF00007865.]

McDowell, R.C., 1986, The Geology of Kentucky-A text to accompany the geologic map of Kentucky: U.S. Geological Survey Professional Paper 1151-H, 68 p. [Also available at https://pubs.usgs.gov/pp/p1151h/.]

McNabb, C.D., 1960, Enumeration of freshwater phytoplankton concentrated on the membrane filter: Limnology and Oceanography, v. 5, no. 1, p. 57-61. [Also available at https://doi.org/10.4319/1o.1960.5.1.0057.]

Monroe, W.H., 1899, A glossary of karst terminology: U.S. Geological Survey Water Supply Paper 1899-K, 29 p.

Omernik, J.M., 1987, Ecoregions of the conterminous United States: Annals of the Association of American Geographers, v. 77, no. 1, p. 118-125, scale 1:7,500,000.

Patton, C.J., and Kryskalla, J.R., 2003, Methods of analysis by the U.S. Geological Survey National Water Quality Laboratory-Evaluation of alkaline persulfate digestion as an alternative to Kjeldahl digestion for determination of total and dissolved nitrogen and phosphorus in water: WaterResources Investigations Report 2003-4174, 33 p. [Also available at https://pubs.usgs.gov/wri/2003/4174/report. pdf.]

Patton, C.J., and Kryskalla, J.R., 2011, Colorimetric determination of nitrate plus nitrite in water by enzymatic reduction, automated discrete analyzer methods: U.S. Geological Survey Techniques and Methods, book 5, chap. B8, 34 p. [Also available at https://pubs.usgs.gov/tm/05b08/contents/ TM5-B8.pdf.]

Paylor, R.L., and Currens, J.C., 2001, Karst occurrence in Kentucky: Kentucky Geological Survey Map and Chart 33, Series XII, 1 sheet.

Ray, J.A., and Currens, J.C., 1998, Mapped karst ground-water basins in the Beaver Dam 30 x 60 minute quadrangle: Map and Chart Series 19, 1 plate, accessed December 12, 2018, at https://kgs.uky.edu/kgsweb/olops/pub/kgs/mc19_11.pdf.

Rosenberry, D.O., and LaBaugh, J.W., 2008, Field techniques for estimating water fluxes between surface water and ground water: U.S. Geological Survey Techniques and Methods, book 4, chap. D2, 128 p. [Also available at https:// doi.org/10.3133/tm4D2.] 
Schaefer, R.T., 2016, Evaluating the influences of karst hydrogeology on freshwater harmful algal blooms in Kentucky lakes: Western Kentucky University, Masters Theses and Special Projects 1619, 95 p., accessed December 12, 2018, at https://digitalcommons.wku.edu/theses/1619.

University of Kentucky and Kentucky Geological Survey, 2018, Kentucky Geologic Map Information Service: accessed December 12, 2018, at https://kgs.uky.edu/kgsmap/kgsgeoserver/viewer.asp.

U.S. Army Corps of Engineers, 2011, Green River watershed section 729 initial watershed assessment: U.S. Army Corps of Engineers, 92 p., accessed December 12, 2018, at https:// www.lrl.usace.army.mil/Portals/64/docs/CWProjects/GreenRiverStudy.pdf.

U.S. Army Corps of Engineers, 2018, Nolin River Lake: U.S. Army Corps of Engineers web page, accessed March 10, 2018, at https://www.lrl.usace.army.mil/Missions/CivilWorks/Recreation/Lakes/Nolin-River-Lake/.

U.S. Climate Data, 2017, Climate, Leitchfield-Kentucky: U.S. Climate Data web page, accessed November 20, 2017, at https://www.usclimatedata.com/climate/leitchfield/kentucky/united-states/usky1073.

U.S. Environmental Protection Agency, 1993, Methods for the determination of inorganic substances in environmental samples: U.S. Environmental Protection Agency Report EPA-600-R-93-100, 17 p., accessed April 18, 2019, at https://nepis.epa.gov/Exe/ZyPDF.cgi/30002U3P. PDF? Dockey=30002U3P.PDF.

U.S. Environmental Protection Agency, 2000, Ambient water quality criteria recommendations - Lakes and reservoirs in nutrient ecoregion IX: Washington, D.C., Office of Water, EPA-822-B-00-011, accessed December 12, 2018, at https://www.epa.gov/sites/production/files/documents/ lakes9.pdf.
U.S. Environmental Protection Agency, 2017, Nutrient policy data - Causes and prevention: U.S. Environmental Protection Agency web page, accessed August 1, 2018, at https://19january2017snapshot.epa.gov/nutrient-policy-data/ causes-and-prevention_.html.

U.S. Environmental Protection Agency, 2018, Nutrient pollution-Harmful algal blooms: U.S. Environmental Protection Agency web page, accessed August 1, 2018, at https://www. epa.gov/nutrientpollution/harmful-algal-blooms.

U.S. Geological Survey, variously dated, National field manual for the collection of water-quality data: U.S. Geological Survey Techniques and Methods, book 9, chaps. A1-A10, variously paged, accessed December 12, 2018, at https:// pubs.water.usgs.gov/twri9A.

VectorMap, 2015, Mission planning software: OceanServer Technology, Inc., accessed December 12, 2018, at https:// ocean-server.com/vectormap/.

Wagner, R.J.; Boulger, R.W., Jr.; Oblinger, C.J.; and Smith, B.A., 2006, Guidelines and standard procedures for continuous water-quality monitors - Station operation, record computation, and data reporting: U.S. Geological Survey Techniques and Methods, book 1, chap. D3, 51 p., plus 8 attachments. [Also available at https://pubs.usgs.gov/ tm/2006/tm1D3/pdf/TM1D3.pdf.]

Woods, A.J., Omernik, J.M., Martin, W.H., Pond, G.J., Andrews, W.M., Call, S.M., Comstock, J.A., and Taylor, D.D., 2002, Ecoregions of Kentucky. (2-sided color poster with map, descriptive text, summary tables, and photographs): Reston, Va., U.S. Geological Survey, scale $1: 1,000,000$.

YSI Incorporated, 2012, 6-series multiparameter water quality sondes-User manual, revision J: Yellow Springs, Ohio, YSI Incorporated Environmental monitoring systems operations manual, 379 p., accessed April 18, 2019, at https://www.ysi.com/File\%20Library/Documents/ Manuals/069300-YSI-6-Series-Manual-RevJ.pdf. 
For more information about this publication, contact:

Director, Ohio-Kentucky-Indiana Water Science Center U.S. Geological Survey

9818 Bluegrass Parkway

Louisville, KY 40299-1906

For additional information, visit:

https://www.usgs.gov/centers/oki-water

Publishing support provided by the

Madison and Rolla Publishing Service Centers 
